\title{
Biocide By-Products in Aquatic Environments
}

Final Report

September 10, 1976 - September 30, 1979

Prepared by R. M. Bean, C. I. Gibson, D. R. Anderson

Pacific Northwest Laboratory

Operated by

Battelle Memorial Institute

Prepared for

U.S. Nuclear Regulatory

Commission 


\section{NOTICE}

This report was prepared as an account of work sponsored by an agency of the United States Government. Neither the United States Government nor any agency thereof, or any of their employees, makes any warranty, expressed or implied, or assumes any legal liability or responsibility for any third party's use, or the results of such use, of any information, apparatus product or process disclosed in this report, or represents that its use by such third party would not infringe privately owned rights.

GPO Sales Program

Division of Technical Information and Document Control

U. S. Nuclear Regulatory Commission Washington, D. C. 20555

Printed copy price: $\$ 4.25$

and 
NUREG/CR-1300

PNL-3271

RE

\section{Biocide By-Products in Aquatic Environments}

Final Report

September 10, 1976 - September 30, 1979

Manuscript Completed: December 1980

Date Published: May 1981

Prepared by

R. M. Bean, C. I. Gibson, D. R. Anderson

Pacific Northwest Laboratory

Richland, WA 99352

Prepared for

Division of Health, Siting and Waste Management

Office of Nuclear Regulatory Research

U.S. Nuclear Regulatory Commission

Washington, D.C. 20555

NRC FIN B2098 

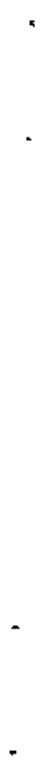


\begin{abstract}
A three-year program has been conducted to study the chemistry and biological effects of products arising from the low-level chlorination of natural waters. These studies are related to environmental concerns arising from the aischarge of chlorine-treated power plant cooling water. The studies have shown that addition of low levels $(2 \mathrm{mg} / \ell$ ) of chlorine to natural waters produces haloforms in concentrations which are orders of magnitude lower than the $\mathrm{LC}_{50}{ }^{\prime} \mathrm{s}$ measured in a number of fresn and salt water organisms. Chlorination also produces nonhaloform lipophilic organohalogen products in concentrations much lower than the naloforms, although no evidence was obtained which suggested significant biomagnification of these during chronic exposure of juvenile salmon to cniorinated fresh water. No dramatic effects were noted in organisms chronically exposed to chlorinated waters, but changes in general conaition were observed.
\end{abstract}




\section{SUMMARY}

This report is intended to provide an overview of a three-year program designed to study the chemistry and biological effects of products arising from the low-level chlorination of water. The purpose of the program was to determine the potential effects of the cooling waters discharged by nuclear power plants which control biofouling through the use of chlorine treatments. Emphas is was placed on identifying the major products of chlorination, particularly those products which had a potential for long-term environmental effects, such as bioaccumulation. Biological experiments were conducted in both fresh and marine waters to determine the long-term effects of low levels of chlorination to a variety of aquatic organisms. In addition, experiments were conducted to determine the toxicity and bioaccumulation potential of chloroform to four species of fresh water fish, and of bromoform to five species of marine organisms. These latter experiments were performed because the haloforms were identified as principal products arising from the chlorination of natural waters.

The detailed methodologies, data, and interpretations leading to the observations, results and conclusions presented in this report can be found in six Topical Reports to the Nuclear Regulatory Commission. The titles and document numbers for these reports are listed in the Preface.

The principal organohalogen products formed from the low level chlorination of natural waters are haloforms; bromoform in saline waters, and chloroform in fresh waters. Concentrations of haloforms produced by addition of 2-4 mg/e chlorine are in the range of a few $\mathrm{ug} / \mathrm{l}$ (parts-perbillion). While other lipophilic organohalogen compounds are produced by the chlorination process, their concentrations appear to be considerabiy less than the part-per-billion level.

Chronic experiments with low levels of chlorine conducted in fresh water using juvenile trout (Salmo gairdneri) and in sea water using littleneck clams (Protothaca staminea) did not produce obvious or dramatic changes in these organisms. For the clams, there was some evidence of growth inhibition, and poor condition was indicated upon histological examination of the clam tissues.

Acute toxicity and biological uptake experiments with bromoform conducted on five marine species produced 96 -hour $\mathrm{LC}_{50}{ }^{\prime} \mathrm{s}$ in the range of about 7 to $40 \mathrm{mg} / \mathrm{l}$ (parts-per-million), approximately one thousand-fold higher than the bromoform concentrations produced by low-level chlorination of sea water. A similar resuit was observed for fresh water organisms. Ninety-six hour LC50's ranged from about 18 to $75 \mathrm{mg} / \mathrm{l}$. Both chloroform in fresh water and bromoform in sea water were found to be rapidly absorbed into the tissues of the organisms investigated, at concentrations approximately that of the surrounding water. Upon transfer to a clean environment, haloforms were found to be rapidly depurated from the tissues of exposed organisms. 
These investigations have shown that addition of low levels of chlorine to natural waters produces haloforms in concentrations orders of magnitude lower than measured 96-hr $\mathrm{LC}_{50}$ 's in several fresh and salt water organisms. Chlorination also produces nonhaloform lipophilic organohalogen components in concentrations much lower than the haloforms, although no evidence was obtained suggesting significant biomagnification of these components. The findings of this program are in need of verification through chemical and biological field studies conducted at actual nuclear power station locales. 
CONTENTS

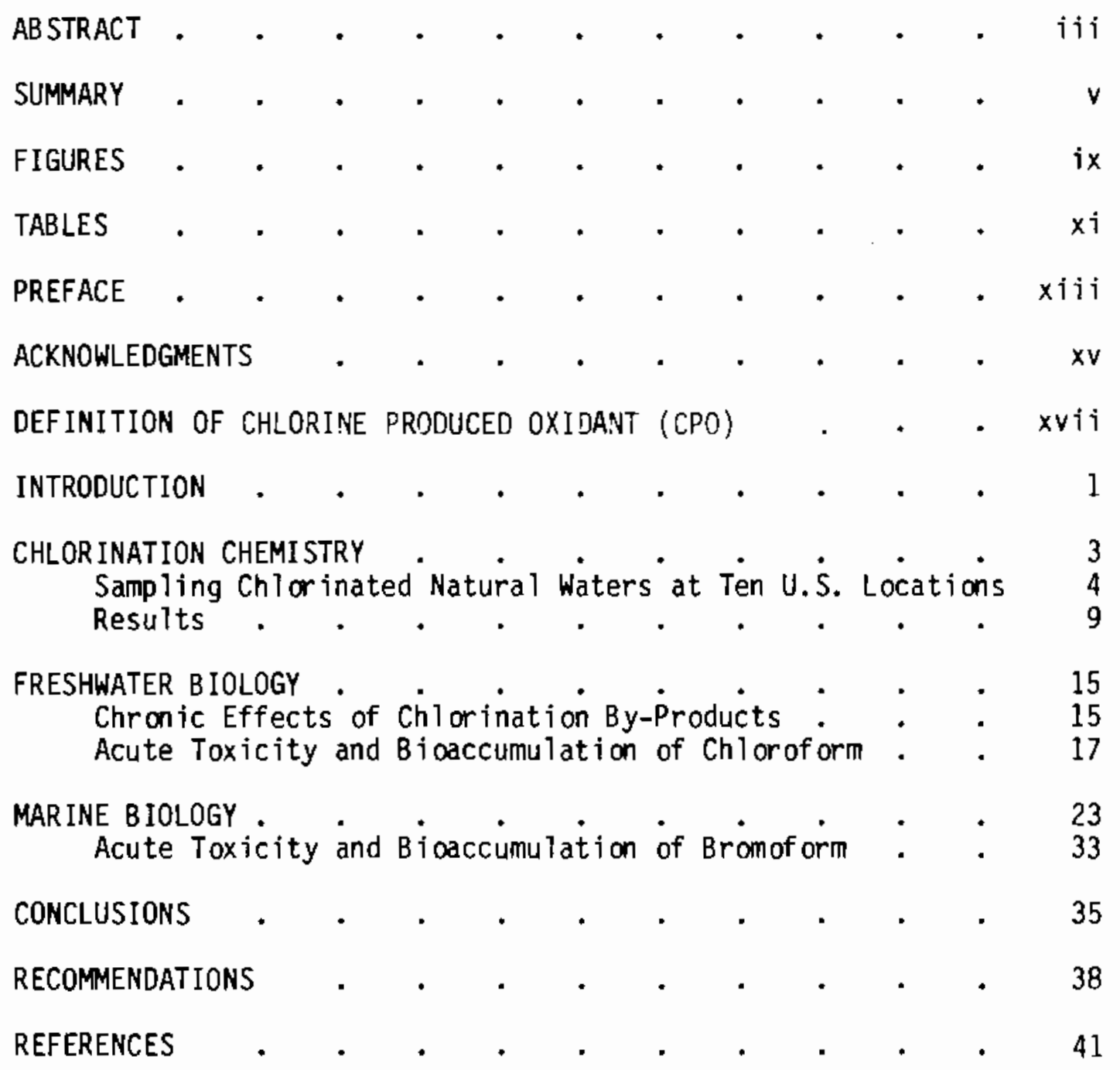

vii 


\section{FIGURES}

1 Locations of Sampling Stations . . . . . . 5

2 Portable Apparatus Constructed to Pump Natural Water and Add Chlorine . . . . . . . . . . 6

3 Schematic of Apparatus for Field Sampling of Chlorinated Natural Waters. $. \quad . \quad . \quad \cdot . \cdot \cdot$.

4 Duplicate Apparatus on Beach at Station 10, San Onofre and Station 4, Lake Michigan . . . . . . 8

5 Exposure System for Chlorination By-Products . . . 16

6 Delivery System Used for Acute Chloroform Tests of Fresh Water Species. . . . . . . .

7 Toxicant Delivery System for Sea Water/Bromoform Bioassays Conducted at Sequim. . . . . . .

8 Section Through Digestive Gland of Clam Exposed in Control Tank for 6 Months . . . . . . . . . . 26

9 Section Through Digestive Gland of Clam Exposed to $100 \mathrm{ppb}$ CPO for 6 Months

10 Section Through Gill of Clam Exposed in Control Tank for 6 Months . . . . . . . . . . .

11 Section Through Gill of Clam Exposed to 100 ppb CPO for 6 Months. . . . . . . . . .

12 Section Through Intestine of Clam Exposed in Control Tank for 6 Months . . . . . . . . .

13 Section Through Intestine of Clam Exposed to $100 \mathrm{ppb}$ CPO for 6 Months 
. 


\section{TABLES}

1 Concentrations of Volatile Organics in Natural Waters as Analyzed by the "Purge and Trap" Method. . . .

2 HaTogen Recovery in Organic Fractions Expressed as $\mu \mathrm{g} / \mathrm{\ell}$ Chlorine $. \quad . \quad . \quad . \quad . \quad . \quad$.

3 Phenols Identified in Chlorinated Water Samples . .

4 Acute Chloroform $\mathrm{LC}_{50}$ 's (ppm) With Largemouth Bass at $19^{\circ} \mathrm{C}$ in Columbia River Water . . . . 20

5 Acute Chloroform $\mathrm{LC}_{50}{ }^{\prime} \mathrm{s}$ (ppm) With Channe1 Catfish at $19^{\circ} \mathrm{C}$ in Columbia River Water . . . .

6 Acute Chloroform LC $_{50}$ 's (ppm) With BTuegill at $25^{\circ} \mathrm{C}$ in Columbia River Water . . . .

7 Acute Chloroform $\mathrm{LC}_{50}{ }^{\prime} \mathrm{s}$ (ppm) With Rainbow Trout at $13^{\circ} \mathrm{C}$ in Columbia River Water . . . . .

8 Bromoform Concentrations in Clams ( $\mu \mathrm{g} / \mathrm{g}$ wet wt) Exposed to Chlorinated Sea Water Containing Sublethal Concentrations of Chlorine Produced Oxidant . . . . . .

9 Mortality and Average Exposure Concentrations for the 96-hr Exposure of Shrimp, Clams, Menhaden and Oysters to Bromoform . . . . . . . . . 

PREFACE

This is the final report for the program on Biocide By-Products in Aquatic Environments covering the period September 10, 1976 through September 30, 1979. Topical reports prepared for the program are:

- Investigation of Halogenated Components

Roger M. Bean

Formed from Chlorination of Natural Waters:

Preliminary Studies, NUREG/CR-1299

- Acute Toxicity and Bioaccumulation of Chloroform to Four Species of Fresh Water Fish

Salmo gairdneri, Rainbow Trout

tepomis macrochirus, Bluegill

Micropterus saimoides, Largemouth Bass

Ictalurus punctatus, Channel Catfish, NUR $\vec{E} \vec{G} / \overrightarrow{C R}-0 \overline{8} 93$

- Chronic Effects of Chlorination By-Products on Rainbow Trout, Salmo gairdneri, NUREG/CR-0892

David R. Anderson

Roger M. Bean

Roger E. Schirmer

- Toxicity, Bioaccumulation and Depuration of

Charles I. Gibson Bromoform in Five Marine Species

Protothaca staminea, Littleneck Clam

Mercenaria mercenaria, Eastern Hard Clam, Quahog

Crassostrea virginica, Eastern oyster

Penaeus aztecus, Brown shrimp

Brevoortia tyrannus, At lantic Menhaden, $N U \overline{R E} G / \overline{C R}-\overline{1} \overrightarrow{2} \overline{9} 7$

- Growth and Histological Effects to Protothaca staminea, (Littleneck Clam) of Long-Term Exposure to Chlorinated Sea Water, David R. Anderson E. William Lusty NUREG/CR-1298

Fredrick $C$. Tone

Peter Wilkinson

J. W. Blaylock

Roger E. Schirmer

Charles I. Gibson

Robert E. Hi]lman

Peter Wilkinson

Dana L. Woodruff

- Analysis of Organohalogen Products from

Chlorination of Natural Waters Under

Roger M. Bean

Simulated Biofouling Control Conditions, NUREG/CR-1301

Dale C. Mann

Robert G. Riley

These documents are available for purchase from the NRC/GPO Sales

Program, U.S. Nuclear Regulatory Commission, Washington, D.C. 20555, and the National Technical Information Service, Springfield, A 22161. 

ACKNUWLEOGMENTS

This work was performed for the U.S. Nuclear Regulatory Commission under a Related Services Agreement with the U.S. Department of Energy, Contract UE-ACU6-76RLO 1830. The authors wish to acknowledge the guidance and assistance provided by Dr. Phillip R. Reed of NRC. They also thank Ur. T. L. Page for his review and comments. Naomi Sherer provided technical editing.

DISCLAIMER

Trade names ano registered trademarks are used to ass ist the reader in replicating the experiments. This use does not constitute endorsement by Battelle Memorial Institute or the USNRC. 


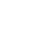




\section{DEFINITION OF CHLORINE PRODUCEO OXIDANT (CPO)}

During the conduct of this research, all measurements of oxidant concentrations produced by the chiorination of water were performed using the amperometric procedure described in Standard Methods ${ }^{\star}$ for total available chlorine (free available + combined availabie chlorine). For many natural waters containina bromide ion, such as estuarine or marine waters, the actual oxidant species may be a combination of both free and available bromine as well as chiorine. For this reason we have used the expression "chlorine produced oxidant" (CPO) unjformly throughout this report. CPO is the concentration of total available oxidant determined by amperometric titration expressed as $\mathrm{mg} / \mathrm{L}$ chlorine, regardless of the actuai oxidizing species in solution.

* Standard Methods for the Examination of Water and Wastewater, 14 th Ed. American Public Health Association, American Water Works Association,, Water Polution Control Federation, Washington, D.C. (1975) pp 322-325. 



\section{INTRODUCTION}

Concern about the presence of halogenated organic compounds in water has been growing since Dowty et al. (1975) detected volatile organochlorine compounds in a New orleans area municipal water treatment facility. This report was rapidly followed with evidence adduced by Rook (1974), Glaze and Henderson (1976), Jolley (1975) and others that the presence of a wide variety of organohalogen compounds in drinking waters and wastewater effluents is a consequence of current chlorination treatment practices. Halogen-containing organic compounds have been reported to adversely affect aquatic biological species through direct toxic action (Roesijadi et a1., 1976), as we17 as through indirect mechanisms such as interference with reproduction success (Gehrs et al., 1974), and interference with photosynthes is (Eppley et 21., 1976). Further, a number of halogenated organic compounds have been found to concentrate in the tissues of aquatic organisms (Zitko and Hutzinger, 1976) which in the case of food fish, increases the hazard of these compounds to human health.

About 26,000 tons of chlorine are used annually in the U.S. in treatment of cooling water for electricity generating plants (Hamilton, 1978), many of which use natural riverine or estuarine waters for once-through cooling. The number of power plants can be expected to grow rapidly as the nation copes with increasing energy demands, with accompanying increases in chlorine admitted to the environment through cooling water treatment. Jolley et al. (1975) provided evidence that chlorinated organics were present in samples of chlorinated cooling waters of fresh water origin and suggested that in estuarine waters organobromine compounds would be formed (Jolley, 1977).

This report is intended to provide an overview of a three-year program designed to study the chemistry and biological effects of products arising from the low-level chlorination of water. The purpose of the program was to determine the potential effects of the cooling waters discharged by nuclear power plants which control biofouling through the use of chlorine treatments. Emphasis was placed on major products of chlorination, particularly those products which had a potential for long term environmental effects, such as bioaccumulation. Biological experiments were conducted in both fresh and marine waters to determine the long-term effects of low levels of chlorination to a variety of aquatic organisms. In addition, experiments were conducted to determine the toxicity and bioaccumulation potential of chloroform to four species of fresh water fish, and of bromoform to five species of marine organisms. These latter experiments were performed because the haloforms were identified as principal products arising from the chiorination of natural waters.

The following three sections of this report summarize the work carried out under the three major Research Tasks of the Program: Chlorination Chemistry, Freshwater Biology, and Marine Biology. The details of 
methods used, complete data sets, interpretations, and preliminary experiments performed are described in six Topical Reports to the Nuclear Regulatory Commission. The titles and document numbers for these reports are $l i s t e d$ in the Preface to this report. 


\section{CHLORINATION CHEMISTRY}

The chemistry studies pursued the following objectives:

- To apply well-documented procedures for sampling, separation, and trace analysis of organohalogen compounds formed from the low-level chlorination of fresh and marine waters.

- To use these methods to study the organic chlorination chemistry of a number of natural water bodies which are actual or potential receiving waters for chlorinated electric power plant cooling water.

- To document the extent to which addition of chlorine to these water bodies results in the formation of lipophilic organohalogen components having the potential for bioaccumulation or biomagnification.

- To determine the extent of formation of other volatile and toxic lower molecular weight halogenated organics; specifically the haloforms and phenols.

In order to accomplish these objectives it was necessary to construct a portable apparatus for the continuous low-level chlorination of natural waters, and to sample and analyze the chlorinated water in a manner consistent with the objectives. Although humic acids from natural waters have been shown to react with chlorine (0liver, 1978), these materials were not considered in our sampling and analytical scheme because of their relatively low potential for immediate aquatic toxicity or bioaccumulation. The method selected for sampling and concentrating lipophilic halogenated organics is the very well documented XAD resin adsorption technique. The method has been exhaustively studied (Junk et al., 1974, 1976) from the points of view of technique, resin purity, and efficiency of recovery of a wide variety of compound types. The technique has been applied extensively to studies of haloorganics in treated wastewater (Glaze, et al., 1975, 1976, 1977). An extensive review of the technique has been pubiished by Dressier (1979).

The use of these columns precluded the concentration of organics with relatively reactive chlorine-nitrogen bonds, such as the chloramines, since prior to column adsorption, destruction of active chlorine with sodium sulfite was necessary to avoid additional chlorination reaction with the material trapped on the column (Bean, 1978; Glaze, 1977).

The andysis of lipophilic halogen compounds adsorbed on the XAD-2 resin using microcoulonetry to determine the total organic chlorine in the adsorbed material is based on the work of Glaze et al. (1977), who suggested that nonhaloform organic halogen trapped on XAD-2 resin was an important water quality parameter. Although we adapted the general 
strategy of determining organic halogen, we also subjected the material to further separation steps in order to classify the type of material adsorbed according to molecular weight and polarity.

The analysis of volatile organics in the chlorinated and control waters was accomplished using both "headspace" (Bush et al., 1977) and "purge-and-trap" methods (Bellar and Lichtenberg, 1974). Methods of this general type have been reviewed recently by Orozd and Novak (1979).

Halogenated phenols are not necessarily considered lipophiles since they do not adsorb we11 on XAD-2 at neutral or basic pH (Junk et al., 1974). However, we chose to add phenols to our analytical scheme because they are a chemical class which is likely to be formed from the chlorination of natural waters.

Substantial effort was made during the course of this program to document the methods used with respect to reproducability, reliability, and efficiency of recovery. A complete discussion can be found in Bean et al. (1980).

Samp? ing Chlorinated Natural waters at Ten U.S. Locations

Ten sites were chosen for sampling (Figure 1). Portable equipment was constructed which continuously pumps water from the natural environment and treats it with from 2 to 5 parts-per-million chlorine as $\mathrm{NaOCl}$ (Figure 2). A schematic of the apparatus is shown in Figure 3 . A baffled chlorine contact chamber allows a residence time of about an hour before the chlorinated water is treated with $\mathrm{Na}_{2} \mathrm{SO}_{3}$ and brought to a $\mathrm{pH}$ of $\sim 4.5$ with reagent grade $\mathrm{H}_{2} \mathrm{SO}_{4}$ by an automatic $\mathrm{pH}$ controller. The treated water is then pumped through the XAD-? column using a positive displacement pump. Two identical devices are used, one for the chlorinated samples and one to simultaneously sample unchlorinated water as a control (Figure 4). To minimize contanination of water samples by the sampling apparatus, the only materials in contact with the sample are polypropylene, tefion, ceramic, and stainless steel.

Other types of water samples were taken from both chlorinated and unchlorinated samples for analyses by methods for which the high volume samples are not appropriate.

- Purge-and-Trap Samples--These samples were analyzed for volatile components using the purge-and-trap technique of Bellar and Lichtenberg (1974).

- Headspace Samples--These samples were and lyzed for haloform according to the metnod of Bush et al. (1977).

- Bulk Sa:nples-approximately 5 liters of untreated water were sampled in bulk as a contingency sample. 


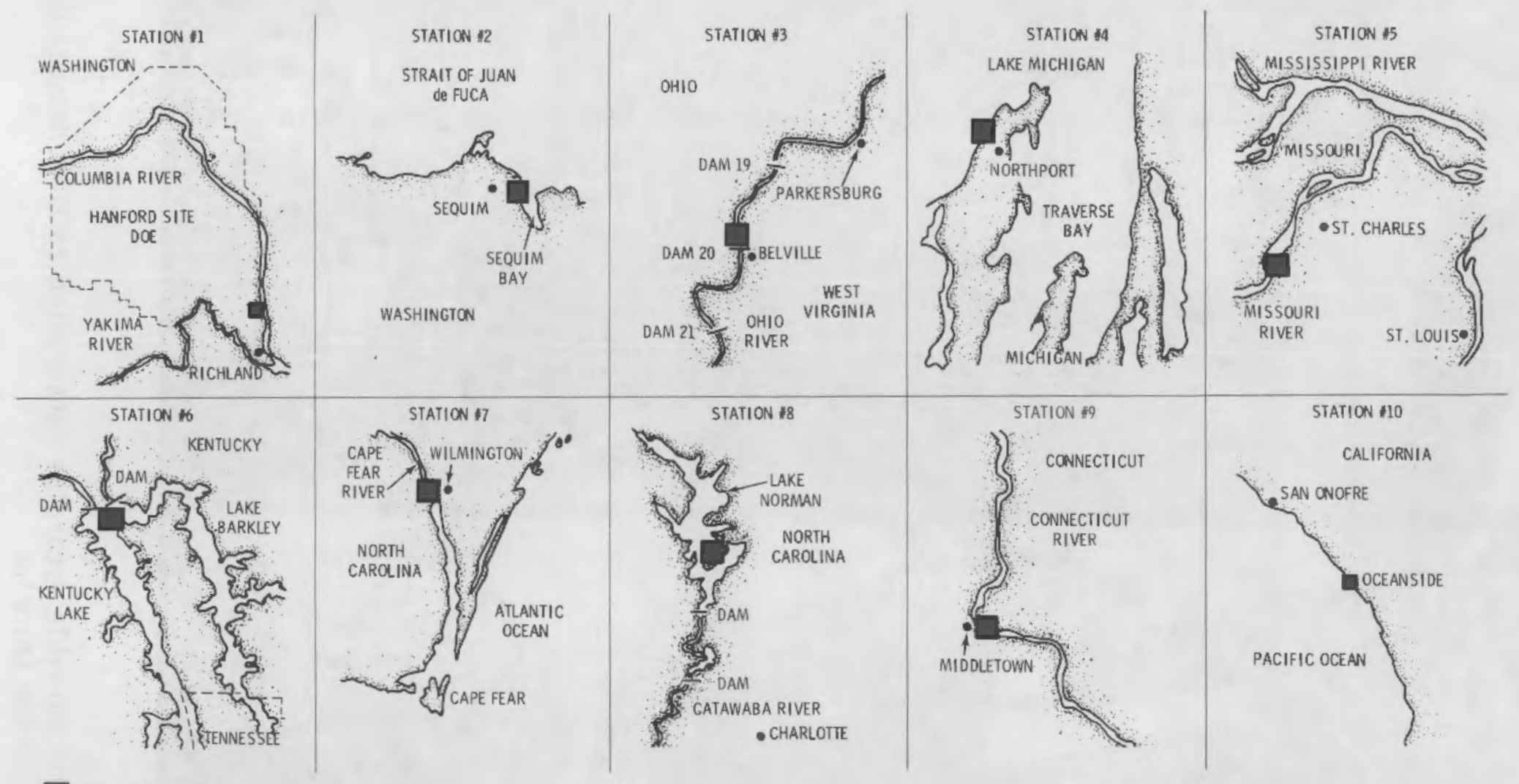

FIGURE 1. Locations of Sampling Stations 


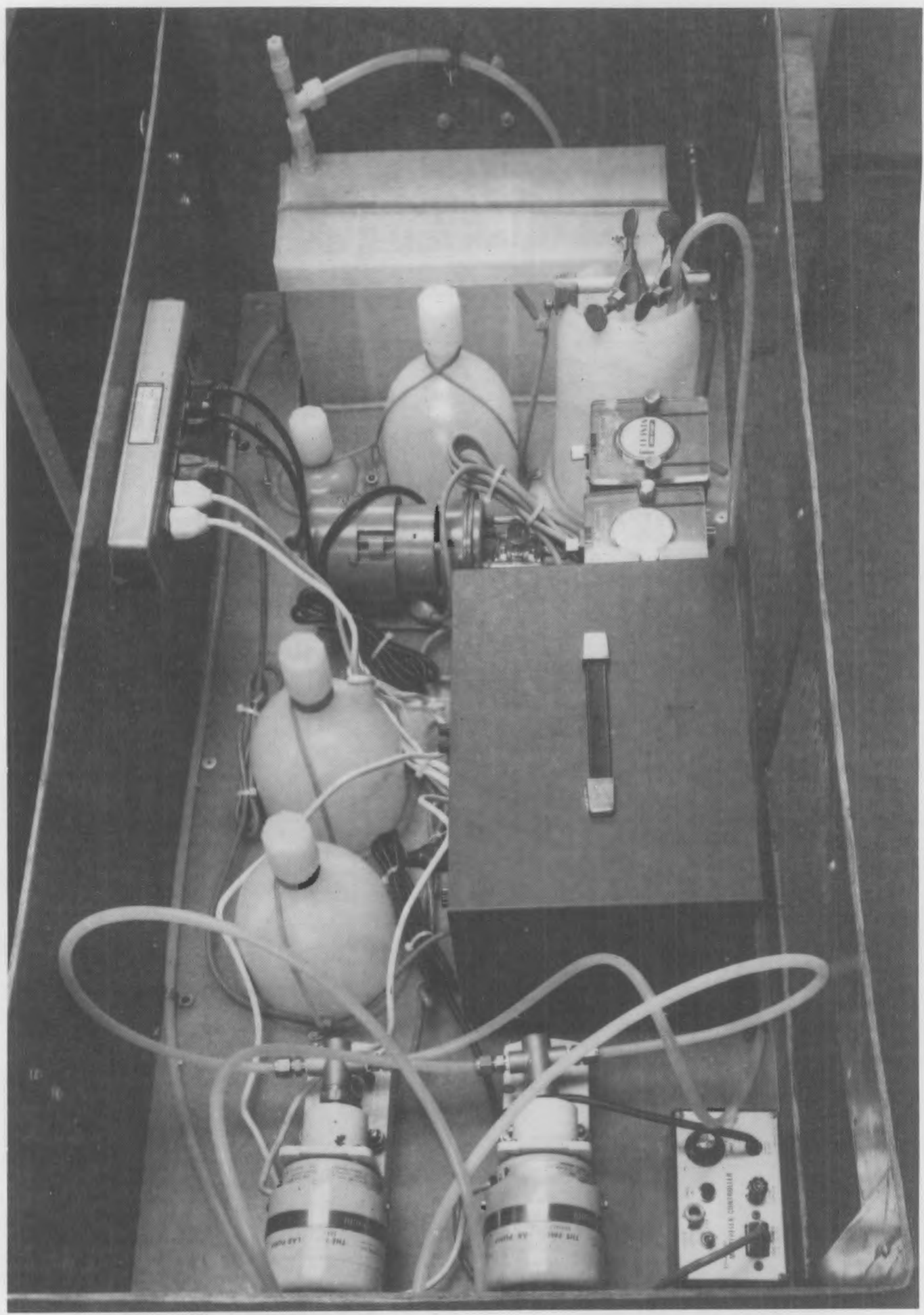

FIGURE 2. Portable Apparatus Constructed to Pump Natural Water and Add Chlorine 


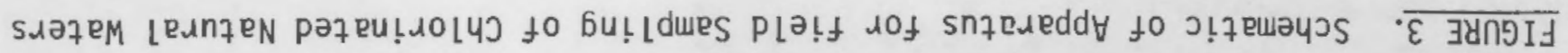

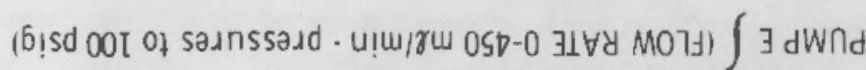

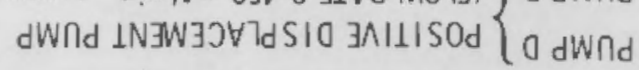

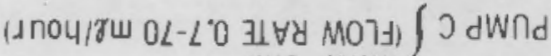

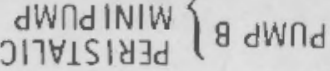

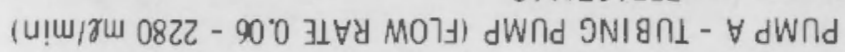

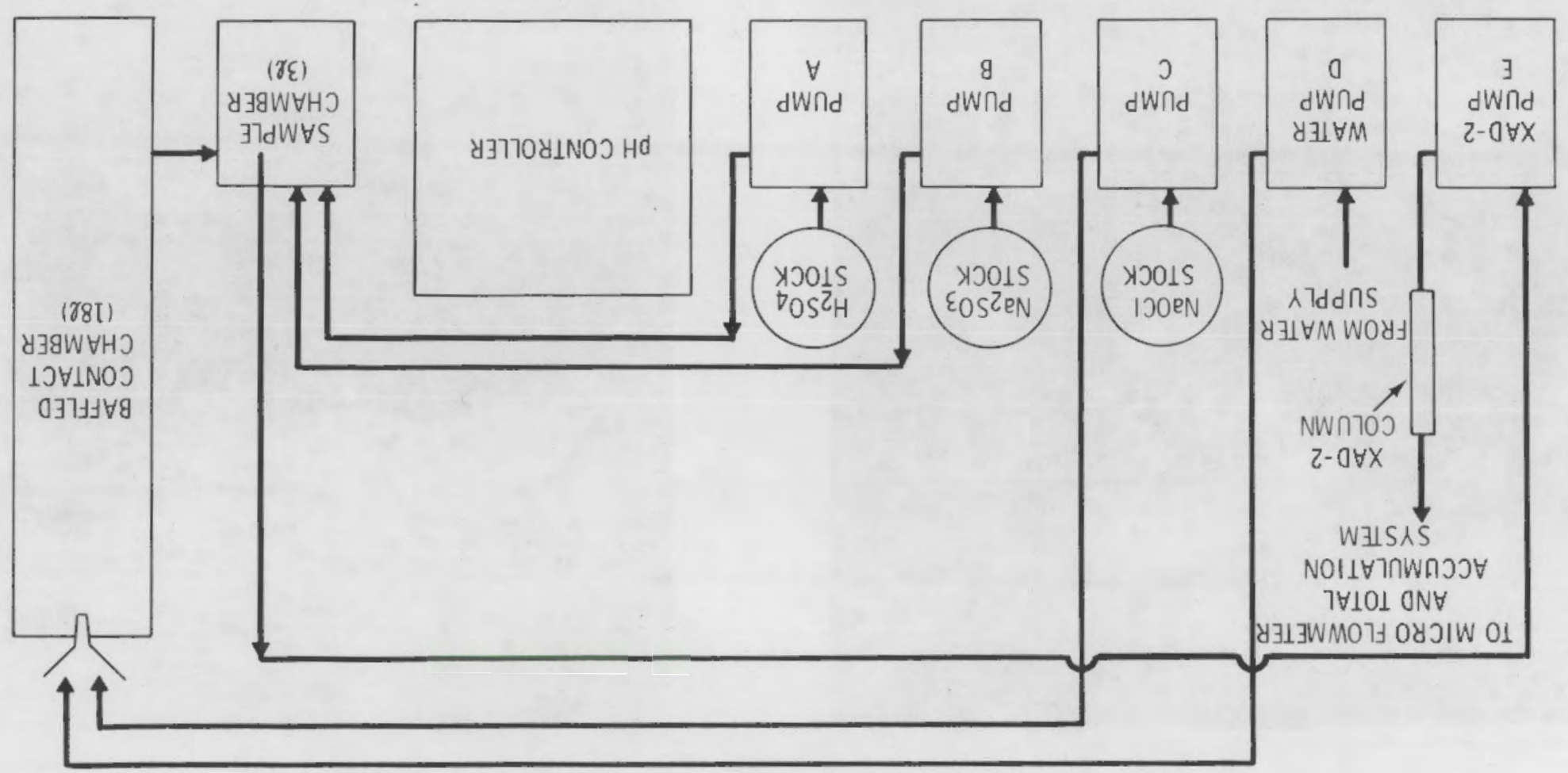



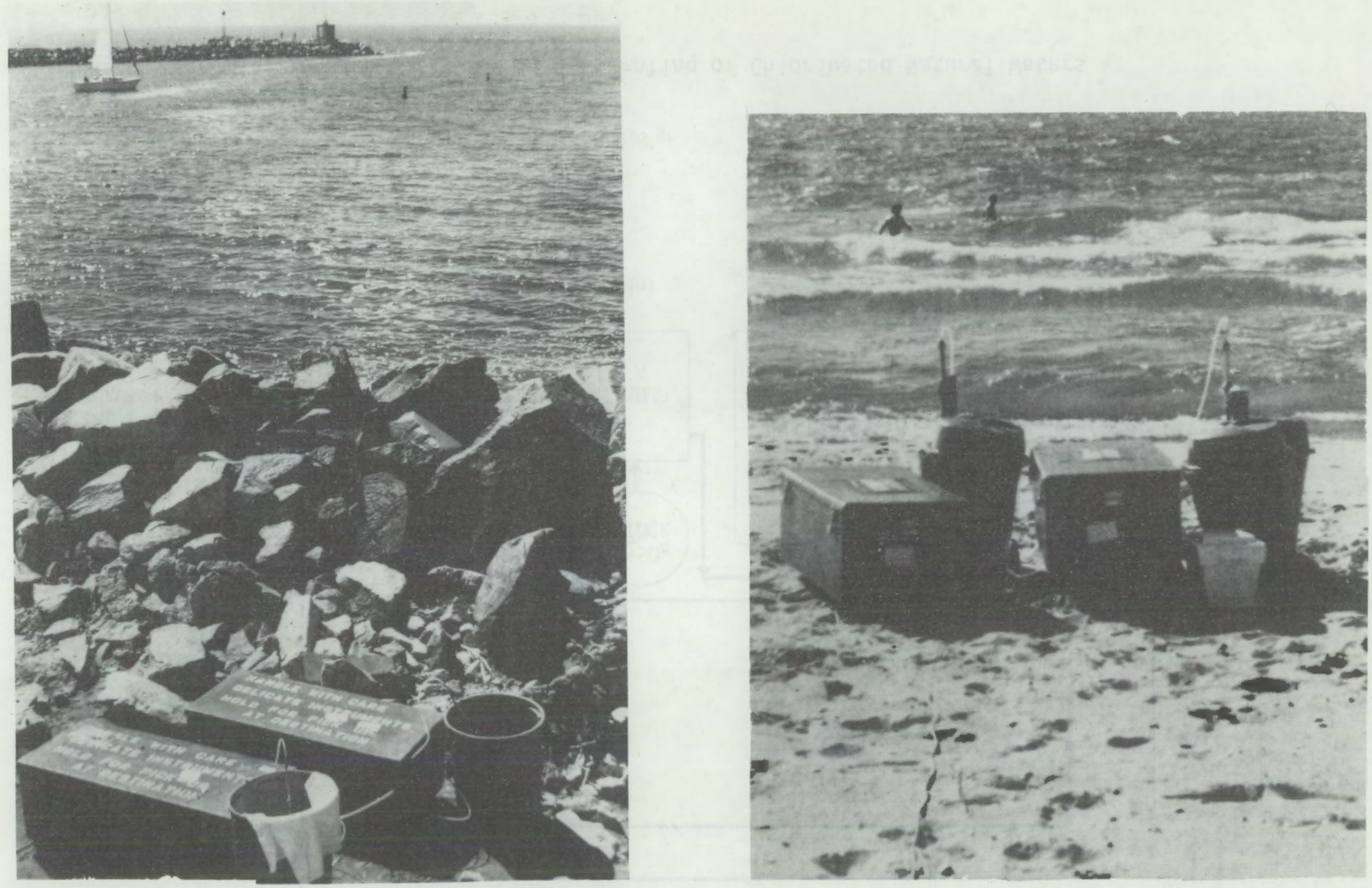

FIGURE 4. Duplicate Apparatus on Beach at Station 10, San Onofre (left) and Station 4, Lake Michigan 
Results

Data on volatile components was generated primarily using the Purge-andTrap (P\&T) technique, since the method is suitable for the identification and quantification of many important volatile toxic organic chemicals, including twenty-three compounds listed by the Environmental Protection Agency as priority pollutants.

The results of the P\&T analys is for nine stations are presented in Table 1. The data are arranged such that the results for the chlorinated water samples are presented at the upper left-hand corner of each box, and the results for the corresponding unchlorinated control are presented in the lower right-hand corner of the same box.

As reported by many workers, haloforms are found to be the principle volatile products arising from the chlorination of natural waters. The data presented in the Table are in complete agreement with these findings. The waters containing significant quantities of sea water (Cape Fear, 50\% sea water; San Onofre, 100\%) produced primarily bromoform, consistent with previous observations (Carpenter, 1978; Helz, 1979). The concentrations of haloforms varied widely among locations, however. Chloroform production at fresh water locations varied from $2 \mu \mathrm{g} / \ell$ ( $L$. Michigan) to $25 \mu \mathrm{g} / \ell$ (Tennessee R.). Traces of chloroform were found in seven of nine control waters.

A major observation to be made about the waters sampled and analysed by P\&T is that they were remarkably free from contamination by volatile nonhaloform organic compounds. Although each GC/MS run was searched using single ion reconstruction technique for all of the 23 priority pollutants, Table 1 lists all of the compounds actually found in the samples which were not found in procedural blanks. Concentrations of haloforms found in our samples were on the same order of magnitude as those found in many drinking waters.

The samples taken by pumping large volumes of water over XAD resins were extracted with ether and the extracts analyzed for chlorinated organic material which was not haloform. The nonhaloform organohalogen material was further separated into three fractions of increasing polarity using silica gel chromatography. The ether extracts and the corresponding fractions were analyzed for total organic halogen by microcoulometry. This data was combined with the Purge-and-Trap data to compare the amount of halogen added as chlorine with the amount of halogen showing up as either haloform or nonhaloform organic chlorine in the chlorinated water. These results, shown in Table 2, Show that on the order of one percent of the added chlorine was used to form haloforms, while the amount of chlorine used to form nonhaloform organohalogen material was much less. Thus, most of the added chlorine, probably greater than $95 \%$, does not form lipophilic organohalogen material. 
TABLE 1. Concentrations of Volatile Organics in Natural Waters as Analyzed by the "Purge and Trap" Method (concentrations are reported in micrograms per 1iter)

\begin{tabular}{|c|c|c|c|c|c|c|c|c|c|c|}
\hline $\begin{array}{l}\text { STATION } \\
\text { (DATE) }(C I \text { ADDED } \mathrm{mg} / \mathrm{l})\end{array}$ & & $\begin{array}{l}\text { DICHLORO } \\
\text { METHANE }\end{array}$ & $\begin{array}{c}\text { CARBON } \\
\text { DISULFIDE }\end{array}$ & $\mathrm{CHCl}_{3}$ & $\mathrm{CHCl}_{2} \mathrm{Br}$ & $\mathrm{CHClBr}_{2}$ & $\mathrm{CHBr}_{3}$ & \begin{tabular}{|l|} 
DICHLORO \\
ETHYLENE
\end{tabular} & $\begin{array}{l}\text { TRICHLORO } \\
\text { ETHYLENE }\end{array}$ & TOLUENE \\
\hline $\begin{array}{l}\text { 1. COLUMBIA R. (WA) } \\
(5 / 79)(2.7-3.0)\end{array}$ & $\begin{array}{l}\mathrm{Cl} \\
\mathrm{N}\end{array}$ & 1 & 720 & $\begin{array}{r}12.0,13.5 \\
t r\end{array}$ & - & - & - & - & * & ++ \\
\hline $\begin{array}{l}\text { 3. OHIO R (WV) } \\
(8 / 78)(4.0-5.3)\end{array}$ & $\begin{array}{l}\mathrm{Cl} \\
\mathrm{N}\end{array}$ & 9.9 & $\begin{array}{r}>20,>20 \\
>20\end{array}$ & $\begin{aligned} & 7.3 .5 .7 \\
& 0.6 \\
&\end{aligned}$ & 3.4 .3 .1 & 0.9 .09 & - & . & - & tr \\
\hline $\begin{array}{l}\text { 4. L. MICHIGAN (MI) } \\
(8 / 78)(3.0-3.8)\end{array}$ & $\begin{array}{l}\mathrm{Cl} \\
\mathrm{N}\end{array}$ & 17,14 & $\begin{array}{r}>20,>20 \\
>20\end{array}$ & 2.7 .2 .0 & $1.8,1.6$ & $0.8,0.5$ & - & - & - & $t r$ \\
\hline $\begin{array}{l}\text { 5. MISSOURI R. (MO) } \\
(9 / 78)(3.6-4.8)\end{array}$ & $\mathrm{Cl}$ & 15 & $>20$ & 11.5 & 10.3 & 5.8 & - & - & - & tr \\
\hline $\begin{array}{l}\text { 6. TENNESSEE R. (KY) } \\
(9 / 78)(4.3-4.7)\end{array}$ & $\begin{array}{ll}\mathrm{Cl} \\
\mathrm{N}\end{array}$ & \begin{tabular}{|l|l|}
17,17 & \\
& 13 \\
\end{tabular} & $\begin{array}{r}>20,>20 \\
>20\end{array}$ & $\begin{array}{r}21.2,24.7 \\
\mathrm{tr} \\
\end{array}$ & 6.0 .7 .4 & $1.1,1.1$ & * & - & - & tr \\
\hline $\begin{array}{l}\text { 7. CAPE FEAR (NC) } \\
(10 / 78)(4.8-5.7)\end{array}$ & $\begin{array}{l}\mathrm{Cl} \\
\mathrm{N}\end{array}$ & 1.3 & $\begin{array}{rr}12,10 & \\
& >20\end{array}$ & tr & 1.9 .2 .6 & $\begin{array}{r}15.7 .17 .8 \\
-\end{array}$ & $54.5 \ddagger$ & - & - & ++ \\
\hline $\begin{array}{l}\text { 8. L. NORMAN (NC) } \\
(10 / 78)(4.1)\end{array}$ & $\begin{array}{l}\mathrm{Cl} \\
\mathrm{N}\end{array}$ & 3.4 & $\begin{array}{r}>20.19 \\
>20\end{array}$ & $4.1,3.1$ & $1.7,1.4$ & - & - & - & - & ++ \\
\hline $\begin{array}{l}\text { 9. CONNECTICUT R. (CT) } \\
(10 / 78)(4.3-5.0)\end{array}$ & $\begin{array}{l}\mathrm{Cl} \\
\mathrm{N}\end{array}$ & 1 & $>20$ & $18.7,24.5$ & 2.3 .3 .4 & - & - & - & - & ++ \\
\hline $\begin{array}{l}\text { 10. SAN ONOFRE (CA) } \\
(2 / 79)(2.9-3.2)\end{array}$ & $\mathrm{Cl}$ & 6 & - & - & - & - & $\begin{array}{r}13.0,17.0 \\
-\end{array}$ & - & * & ++ \\
\hline
\end{tabular}

- $=$ not detected

tr $=$ trace (present in concentrations less than $0.5 \mu \mathrm{g} / \mathrm{\ell}$ )

* = shown to be present in single ion reconstructed chromatogram

$++=$ present at the severai $\mu \mathrm{g} / \ell$ level

$\ddagger=$ analyzed using XAD- 2 method 
TABLE_2. Halogen Recovery in Organic Fractions Expressed as $\mu \mathrm{g} / \ell \mathrm{Ch}$ lorine

\begin{tabular}{|c|c|c|c|c|c|c|}
\hline \multirow{2}{*}{\multicolumn{2}{|c|}{$\begin{array}{l}\text { STATION } \\
\text { (DATE) (Cl ADDED } \mathrm{mg} / \mathrm{l})\end{array}$}} & \multirow{2}{*}{$\begin{array}{l}\text { CHLORINE TO } \\
\text { HALOFORMS } \\
\text { (PURGE \& TRAP) }\end{array}$} & \multirow{2}{*}{$\begin{array}{c}\text { CHLORINE TO } \\
\text { NONHALOFORMS } \\
(<800 \mathrm{MW})\end{array}$} & \multicolumn{3}{|c|}{ CHLORINE TO SILICA GEL FRACTIONS } \\
\hline & & & & HEX/ETHER & ETHER & $\mathrm{MeOH}$ \\
\hline $\begin{array}{l}\text { 1. COLUMBIA R. (WA) } \\
(5 / 79)(2.7-3.0)\end{array}$ & $\begin{array}{l}\ddagger \mathrm{Cl} \\
\ddagger \mathrm{N}\end{array}$ & 11.9 & .37 & .19 & .04 & .06 \\
\hline $\begin{array}{l}\text { 2. SEOUIM BAY (WA) } \\
(8 / 78)(1.8)\end{array}$ & $\begin{array}{l}\mathrm{Cl} \\
\mathrm{N}\end{array}$ & $\begin{array}{l}8.7^{*} \\
\text { nd }\end{array}$ & 1.48 & .37 & .23 & .04 \\
\hline $\begin{array}{l}\text { 3. OHIO R. (WV) } \\
(8 / 78)(4.0-5.3)\end{array}$ & $\begin{array}{ll}\mathrm{Cl} \\
\mathrm{N}\end{array}$ & 8.4 & $.49, .62$ & $.07, .13$ & .07 .07 & $.02, .09$ \\
\hline $\begin{array}{l}\text { 4. L. MICHIGAN (MI) } \\
(8 / 78)(3.0-3.8)\end{array}$ & $\mathrm{Cl}$ & 3.5 & .39 .40 & $.10 . .11$ & $.06, .04$ & $.01, .01$ \\
\hline $\begin{array}{l}\text { 5. MISSOURI R. (MO) } \\
(9 / 78)(3.6-4.8)\end{array}$ & $\begin{array}{l}\mathrm{Cl} \\
\mathrm{N}\end{array}$ & 19.9 & $84, .99$ & .20 .22 & $.32, .18$ & $.07, .07$ \\
\hline $\begin{array}{l}\text { 6. TENNESSEE R. (KY) } \\
(9 / 78)(4.3-4.7)\end{array}$ & $\begin{array}{l}\mathrm{Cl} \\
\mathrm{N}\end{array}$ & 25.4 & $1.26,1.28$ & $.35, .21$ & .40 .39 & $.21, .14$ \\
\hline $\begin{array}{l}\text { 7. CAPE FEAR (NC) } \\
(10 / 78)(4.8-5.7)\end{array}$ & $\begin{array}{l}\mathrm{Cl} \\
\mathrm{N}\end{array}$ & $32.9^{*}$ & 3.14 & .94 & .22 & nd \\
\hline $\begin{array}{l}\text { 8. L. NORMAN (NC) } \\
(10 / 78)(4.1)\end{array}$ & $\begin{array}{l}\mathrm{Cl} \\
\mathrm{N}\end{array}$ & 4.2 & 1.04 .1 .03 & $.21, .23$ & $.42, .37$ & $.16, .08$ \\
\hline $\begin{array}{l}\text { 9. CONNECTICUT R. (CT) } \\
(10 / 78)(4.3-5.0)\end{array}$ & $\begin{array}{l}\mathrm{Cl} \\
\mathrm{N}\end{array}$ & 21.1 & .57 & .15 & .30 & .07 \\
\hline $\begin{array}{l}\text { 10. SAN ONOFRE (CA) } \\
(2 / 79)(2.9-3.2)\end{array}$ & $\mathrm{Cl}$ & 6.3 & 1.43 & .58 & .43 & .13 \\
\hline
\end{tabular}

$\mp C 1=$ Chlorinated

$\mathbf{N}=$ Nonchlorinated

*Bromoform analysis performed using XAD-2 adsorption method 
When XAD-2 ether extracts were examined by gas chromatography-mass spectrometry (GC/MS) for halogen-containing components, no major components in the samples were found to contain halogen. Thus when the quantity of organic halogen formed from water chlorination is kept in mind, it is apparent that individual lipophilic nonhaloform organohalogen compounds are present in the chlorinated water in concentrations well under one part-per-billion. GC/MS analysis of carbonate extracts of the XAD-2 samples did show traces of halogenated phenol components in seven of the ten stations investigated. Their concentrations were also estimated to be considerably less than one part-per-billion in the chlorinated water. A listing of the halogenated phenols identified is given in Table 3 . 
TABLE 3. Phenols Identified in Chlorinafed Water Samples. (a) (Retention times for phenols relative to trichlorophenol)(b)

\begin{tabular}{|c|c|c|c|c|c|c|c|}
\hline Phenolic Compound & $\begin{array}{c}\# 1 \\
\text { Columbia } \\
\text { River } \\
\end{array}$ & $\begin{array}{l}\text { \#3 } \\
\text { Ohio } \\
\text { River } \\
\end{array}$ & $\begin{array}{c}\# 5 \\
\text { Missouri } \\
\text { River } \\
\end{array}$ & $\begin{array}{c}\# 6 \\
\text { Tennessee } \\
\text { River } \\
\end{array}$ & $\begin{array}{l}\# 7 \\
\text { Cape } \\
\text { Fear } \\
\end{array}$ & $\begin{array}{l}\# 8 \\
\text { Lake } \\
\text { Norman } \\
\end{array}$ & $\begin{array}{c}\# 9 \\
\text { Connecticut } \\
\text { River } \\
\end{array}$ \\
\hline ChIorophenol & & & 0.637 & & & 0.680 & $0.693(?)$ \\
\hline Methylchlorophenol & & 0.802 & 0.807 & & & & 0.830 \\
\hline Dimethylchlorophenol & & & & 1.036 & & & 1.021 \\
\hline Dich1orophenol & $\begin{array}{l}0.854 \\
0.885\end{array}$ & $\begin{array}{l}0.875 \\
0.850\end{array}$ & 0.821 & $\begin{array}{l}0.821 \\
0.860\end{array}$ & & $0.844(?)$ & 0.855 \\
\hline Bromophenol & & & $1.086(?)$ & & & & \\
\hline Methyldichlorophenol & $1.055(?)$ & & 1.081 & & & & $\begin{array}{l}0.989 \\
1.064\end{array}(?)$ \\
\hline Dimenthyldichlorophenol & & & & & & & 1.131 \\
\hline Trich7orophenol & 1.000 & $1.000(?)$ & 1.000 & 1.000 & 1.000 & 1.000 & 1.000 \\
\hline 8romochlorophenol & & & 0.946 & 0.955 & & & 0.961 \\
\hline Bromodichiorophenol & & & $\begin{array}{l}1.130 \\
1.139(?)\end{array}$ & $1.135(?)$ & $\begin{array}{l}1.144 \\
1.135\end{array}$ & & \\
\hline Dimethyldibromophenol & & & & & 1.423 & & \\
\hline Dibromochlorophenol & & & $\begin{array}{l}1.265 \\
1.269\end{array}$ & & $\begin{array}{l}1.265 \\
1.274\end{array}$ & & \\
\hline Tribromophenol & & & & & 1.395 & & \\
\hline
\end{tabular}

a question mark indicates that spectral quality left doubt as to identity

b Two retention times indicates two isomers found 



\section{FRESHWATER BIOLOGY}

The study on effects of chlorination by-products in freshwater systems was conducted in two phases: first, chronic exposure of freshwater fish to chlorination by-products was undertaken to determine long range effects on mortality, growth, and conditon; second, the effects of chlor of orm on mortality and bioaccumulation were investigated on four freshwater fish species.

\section{Chronic Effects of Chlorination By-Products}

The chronic chlorination by-products study of rainbow trout was made on an exposure system that was designed to maximize production of chlorination by-products at chlorination levels of 1-2 ppm under a temperature regime which could be expected to occur under normal power plant operations. Chlorinated and unchlorinated river water were proportionally mixed to produce the maximum test concentration of approximately 0.02 ppm chlorine produced oxidant (CP0) which is considered the $100 \%$ test group. The four other test groups were based upon dilutions of $75 \%$, $50 \%, 25 \%$, and $12 \%$ of the $100 \%$ test concentration and a control.

Initially, two hundred fish were randomly selected and placed in each duplicate aquarium $f$ or each test concentration (Figure 5). The sequence of test concentrations was selected from a random numbers table.

Test mortality was low, approximately one fish per aquarium per week. There was no apparent effect on mortality of chronic exposure to low level CPO at any concentration tested. However there was a statistically significant difference between the $50 \%$ group and controls indicating the controls were in better condition than the $50 \%$ group. This was corroborated also by the length and weight differences between control and the $50 \%$ group. The observed difference in the $50 \%$ test group was not judged to be a result of the exposure to CPO or chlorination by-products. Results of morphological measurements of fish from each subsample in the test reveal little difference in mean and range for fork length, weight and condition factor at each subsample. An increase in both length and weight with time was found, as expected.

The results have indicated that there was no effect on growth or mortality resulting from chlorination by-product toxicity. Nevertheless, an effect on the health of the test fish as indicated by condition factor was found.

Chlor of orm was found in fish tissues, but no difference was noted between exposed and control fish. The absence of a difference in levels between the two groups is not suprising considering the chloroform level in the control aquarium water was approximately one quarter the level found in the treated water. The identity and concentrations of chloroform in the tissues of exposed fishes was confirmed by GC/MS. 


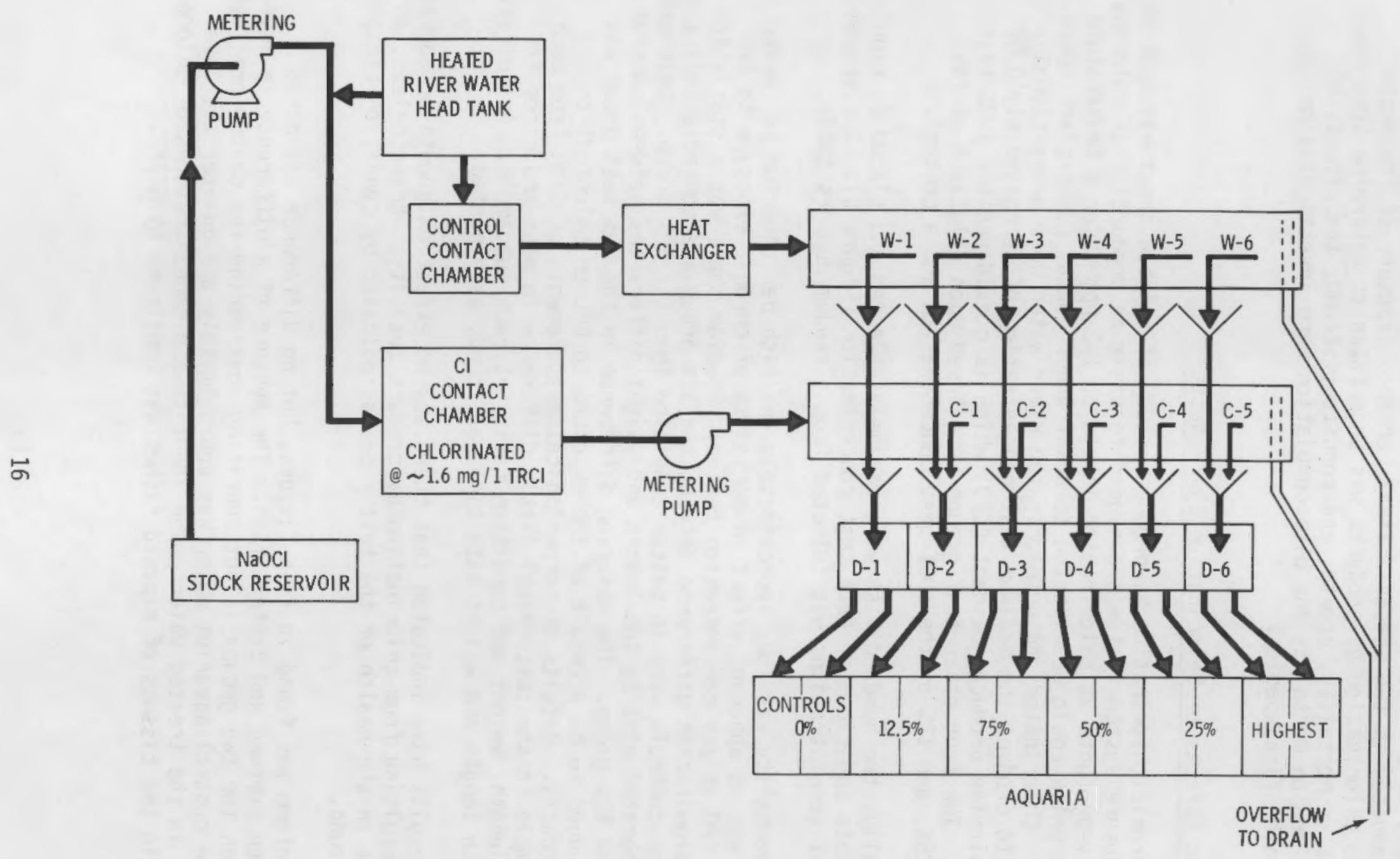

FIGURE 5. Exposure System for Chlorination By-Products 


\section{Acute Toxicity and Bioaccumulation of Chlor of orm}

Objectives of this phase of the study were to determine the acute toxicity and bioaccumulation of chlor of orm, a major fresh water chlorination by-product, to four species of fresh water fishes. Choice of chlor of orm as a toxicant was based on results of the analytical phase of the Chlorination By-Products Program. Studies conducted to determine the biologically available chlorinated organics produced from chlorination of fresh water across the United States indicated that chloroform was the major chlorination by-product produced in fresh water. Therefore we conducted acute $(96-\mathrm{hr})$ toxicity studies with rainbow trout (Salmo gairdneri), bluegill (Lepomis macrochirus), channel catfish (Ictalurus punctatus) and largemouth bass (Micropterus salmoides). The species were selected because of their economic and ecological importance in aquatic ecosystems near power plants using fresh water as a secondary coolant. A major objective of the acute toxicity tests was to provide data for the evaluation of potential toxicity resulting from chlor of orm produced during power plant chlorination. Acute $96-\mathrm{hr} \mathrm{LC}_{50}$ 's were determined and compared to expected levels of chloroform produced during power plant chlorination.

Chlor of orm saturated water cannot be effectively prepared by simply stirring the two together due to the slow rate of solution, so a flowthrough toxicant delivery system was constructed (Figure 6) that produced a continuous supply of stock solution saturated with chlor of orm at $8000 \mathrm{ppm}$. A complete description of the apparatus can be found in Anders on and Lusty (1980). Toxicity studies were conducted on the four species for $96 \mathrm{hr}$.

In order to minimize effects of fish growth on the test results, the complete series of toxicity tests for each species except for bluegill were completed before testing another species. Testing was suspended for bluegill during an outbreak of columnaris infection. Apparently the stress of handling fish prior to the outset of the bioassay was sufficient to cause an outbreak of the disease. Chlor of orm concentrations greater than $14.9 \mathrm{ppm}$ were sufficient to inhibit or reduce the columnaris infection.

The experimental design of the toxicity tests is in accordance with that recommended by Sprague (1973). Chlorof orm concentration sequence in the test system is random. The sequence of loading fish into the aquaria for each test is performed following a random numbers table. This randomization minimizes the possibility of the testing system arrangement and fish loading selectivity on the outcome of the toxicity test. 

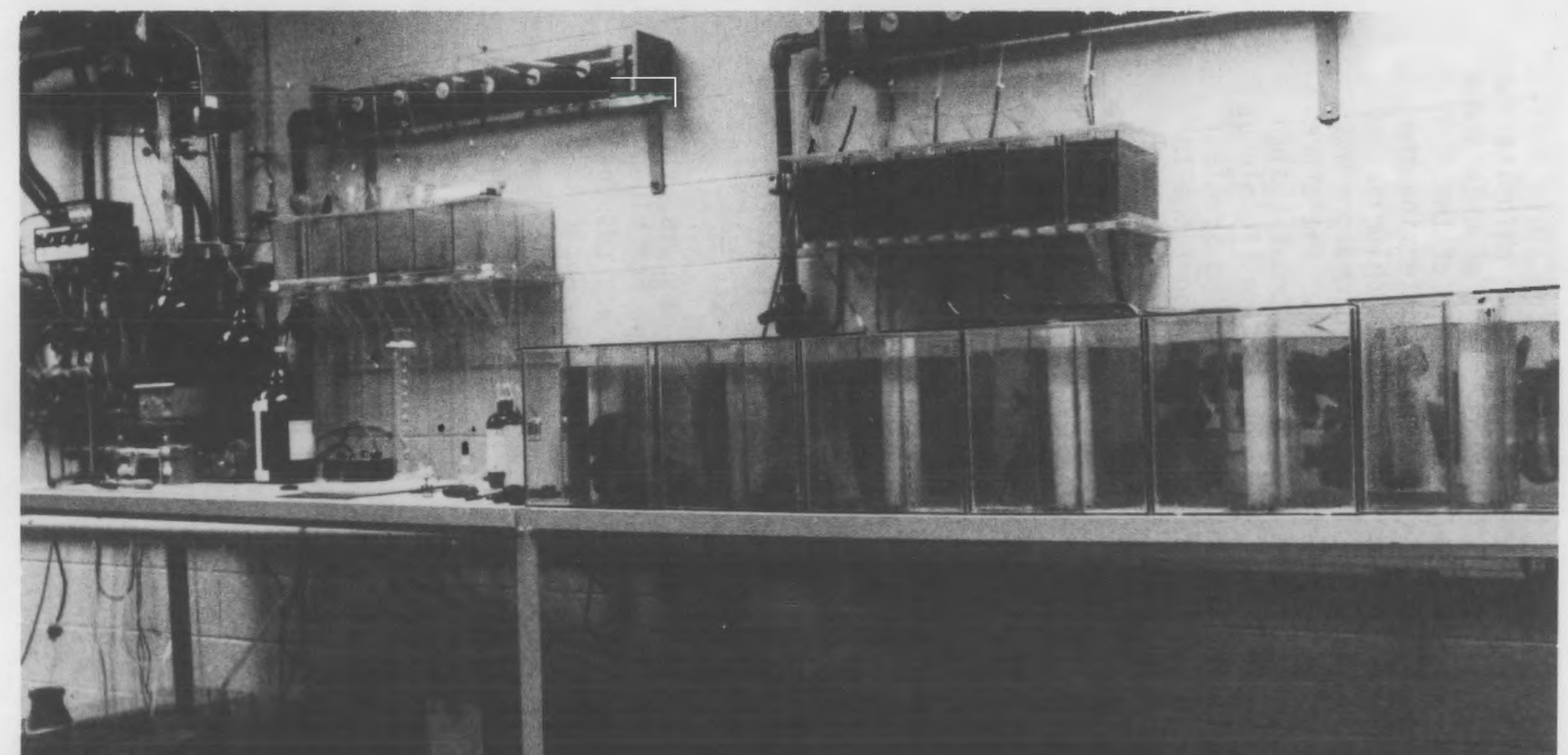

FIGURE 6. Delivery System Used for Acute Chloroform Tests of Fresh Water Species 
Statistical analyses of the toxicity test results were analyzed on a PDP 1170 computer. Stephan's (1977) program was used to compute the LC 50 's and $95 \%$ confidence intervals. The program computes $\mathrm{LC}_{50}$ 's by probit, moving average and binomial computational procedures.

Test fish can be placed in two groups by sensitivity to chloroform. The first group, trout and bluegill, with $96-\mathrm{hr} \mathrm{LC}_{50}$ 's less than $25 \mathrm{ppm}$ chloroform and the second group, largemouth bass and catfish, with LC 50 's greater than 25 ppm (Tables 4-7).

Distinct behavioral differences were noted between largemouth bass exposed to toxic levels of chloroform and controls. Exposed fish exhibited color changes, and "head down" position while resting. 0ccasionally the fish in the "head down" posture would swim energetically and erratically colliding with the top and sides of the aquarium. The energetic swimming was intermittent and occasionally concomitant with a sudden noise in the room. The behavioral response may be described as an excessive startle response.

Preliminary studies were conducted with trout tissues in order to determine the number of methanol extractions required to remove chloroform from fish tissue. These preliminary studies indicated that $97.5 \%$ of the chloroform was removed during the first two chloroform extractions of fish tissue. Only in very few instances was any chloroform found in the third extraction. The samples were analyzed in a random order to minimize analytical bias.

Rainbow trout exhibited the highest bioaccumulation factor of any of the species tested. Within $1 \mathrm{hr}$ of exposure, the tissue level of chloroform in trout was $4 \mathrm{\mu g}$ of chloroform per gram of fish tissue. This is the approximate tissue level achieved in other test species at $4 \mathrm{hr}$ of exposure. Chloroform level in trout tissue then nearly doubled to $7 \mu \mathrm{g}$ per gram of tissue at $4 \mathrm{hr}$. At the $24 \mathrm{hr}$ sampling, the mean chloroform concentration of $5.5 \mu \mathrm{g} \mathrm{CHCl} 3 / \mathrm{g}$ tissue, was lower than at $4 \mathrm{hr}$. Preliminary tests were conducted with a much higher level of chloroform than the one per million level finally used to determine the period of exposure and depuration. They showed that chloroform levels did not increase from 4 to $8 \mathrm{hr}$. The 8 -hr sampling time was eliminated and replaced by a 24-hr sampling to provide time for an equilibrium between fish and water concentrations to occur.

Fish sensitivity to chloroform as indicated by $96-\mathrm{hr} \mathrm{LC}_{50}$ 's ranges from $18 \mathrm{ppm}$ for rainbow trout and bluegill to 51 and $75 \mathrm{ppm}$ for largemouth bass and channel catfish, respectively. Although the 96-hr LC50's provide an indication of the sensitivity of fish to chloroform, examination of the mortality rates during each toxicity test provides additional information. Mortality rates for bluegill and largemouth bass were high during the first day of exposure with little further mortality occurring later in the toxicity test. Trout and catfish, which had the 
TABLE 4. Acute Chloroform LC $50^{\prime}$ 's (ppm) With Largemouth Bass at $19^{\circ} \mathrm{C}$ in Columbia River Water

Census Times

Toxicity

Test No.

16

17

18

19

20

21
$12 \mathrm{hr}$

$24 \mathrm{hr}$

$48 \mathrm{hr}$

$96 \mathrm{hr}$

$\begin{array}{cccc}a & a & a & a \\ 56.2 & 56.2 & b & b \\ 50.4 & 50.4 & 50.4 & c \\ 55.8 & 55.8 & 55.8 & 55.8 \\ 52.5 & 52.5 & 52.5 & 52.5 \\ 45.4 & 45.4 & 45.4 & 45.4\end{array}$

a No mortalities occurred in all test groups.

b Only one mortality occurred, insufficient data for $\mathrm{LC}_{50}$ calculation.

c Test terminated prior to the $48-h r$ census time.

TABLE 5. Acute Chloroform $\mathrm{LC}_{50}$ 's (ppm) With Channel Catfish at $19^{\circ} \mathrm{C}$ in Columbia River Water

Census Times

$12 \mathrm{hr}$

$24 \mathrm{hr}$

$48 \mathrm{hr}$

$96 \mathrm{hr}$

Toxicity

Test No.

11
22
25
26
27
28

$a$
$a$
$135^{c}$
$126^{d}$
$a$

$\begin{array}{cc}b & b \\ a & a \\ a & a \\ b & b \\ 101^{e} & b \\ a & 75^{d}\end{array}$

a Insufficient mortality to compute an $\mathrm{LC}_{50}$.

b Test terminated.

c Binomial method.

d Moving average method.

e Probit method. 
TABLE 6. Acute Chloroform $L_{50}$ 's $(\mathrm{ppm})$ With Bluegill at $25^{\circ} \mathrm{C}$ in Columbia River Water

\begin{tabular}{lcccc} 
Census Times & $12 \mathrm{hr}$ & $24 \mathrm{hr}$ & $48 \mathrm{hr}$ & $96 \mathrm{hr}$ \\
\hline $\begin{array}{l}\text { Toxicity } \\
\text { Test No. }\end{array}$ & & & & \\
& & & & \\
2 & 17.1 & 17.1 & 16.3 & 16.2 \\
3 & 23.9 & 21.8 & $\mathrm{a}$ & $\mathrm{a}$ \\
8 & 24.2 & 24.2 & 23.1 & 22.3 \\
9 & 16.2 & 16.2 & 14.6 & 13.3 \\
10 & 24.4 & 20.2 & 19.4 & 18.3 \\
12 & 24.1 & 24.1 & 22.3 & 20.8
\end{tabular}

a Test terminated prior to $48-\mathrm{hr}$ census time due to
disease mortality in the control aquarium.

TABLE 7. Acute Chloroform $\mathrm{LC}_{50}$ 's (ppm) With Rainbow Trout at $13^{\circ} \mathrm{C}$ in Columbia River Water

\begin{tabular}{lcccc} 
Census Times & $12 \mathrm{hr}$ & $24 \mathrm{hr}$ & $48 \mathrm{hr}$ & $96 \mathrm{hr}$ \\
\hline $\begin{array}{l}\text { Toxicity } \\
\text { Text No. }\end{array}$ & & & & \\
\hline \multicolumn{5}{l}{} \\
5 & - & - & 21.4 & 18.2 \\
6 & - & - & - & 18.4 \\
7 & 37.1 & 26.1 & 23.6 & 22.1 \\
13 & - & - & 18.6 & 15.1 \\
15 & 24.5 & 20.0 & 19.3 & 17.1
\end{tabular}


lowest and highest $96-\mathrm{hr} L_{50}$ 's respectively, demonstrated similar mortality patterns at test concentrations. They tended to exhibit an initial tolerance and low mortality with increasing mortality later in the toxicity test. Although with relatively high chloroform concentrations in regard to the $L C_{50}$, mortality was high during the initial portion of the test. 


\section{MARINE BIOLOGY}

The Marine and Estuarine Biology Task was designed and performed as a supportive effort to the main objective of the program. The primary objective of this task was to provide a laboratory system capable of producing chlorinated sea water that would be representative of cooling system discharge water from a steam electric station, using unpolluted sea water as cooling system circulating water. In addition to this primary objective, data on the biological effects of chlorinated sea water and its by-products were to be obtained as time and resources permitted. Where halogenated by-products of sea water chlorination were identified, preliminary investigation of their toxicity and potential for bioaccumulation were to be tested.

Using these guidelines the following program outline was formulated:

(1) A flow-through sea water system that was chlorinated at a rate of approximately $1.5 \mathrm{ppm} \mathrm{Cl} 2$ would be constructed and operated at the Sequim Marine Research Laboratory. Sequim Bay, the source of sea water for the Marine Research Laboratory, is a relatively pristine body of water that has no local industrial contamination and only minimal potential domestic contamination. Therefore, it was felt that the likelihood of background halogenated organics would be minimal, and the problems of background interference in attempting to identify those compounds created by chlorination would be minimized.

(2) In conjunction with the operation of this system, littleneck clams, Protothaca staminea, would be exposed to selected dilutions of the chlorinated sea water to look for acute and chronic effects and bioaccumulation of halogenated organics. The littleneck clam was selected because of its economic and recreational importance, the fact that it is nonmobile and, therefore, likely to be subjected to a consistent exposure regime in the natural environment, and the demonstrated bioaccumulation ability of molluscs for halogenated organics.

(3) When halogenated organic products were identified, their toxicity and bioaccumulation would be tested with representative marine species.

The flowing sea water system, providing a continuous source of chlorinated sea water, began operation in October of 1977. Initially, a system using the Mount-Brungs diluter concept was used. However, because of difficulty in maintaining this type of system with sea water, it was decided to switch to a manifold-type system. The manifold-type system that was developed and put into use in December 1977 is shown in Figure 7. It proved to be a very reliable design and it functioned without problems from December 1977 through November 1978, when long-term testing was terminated. The results of the chemical analys is of water from this system for halogenated organics are discussed in the Chemistry Section of this report. 


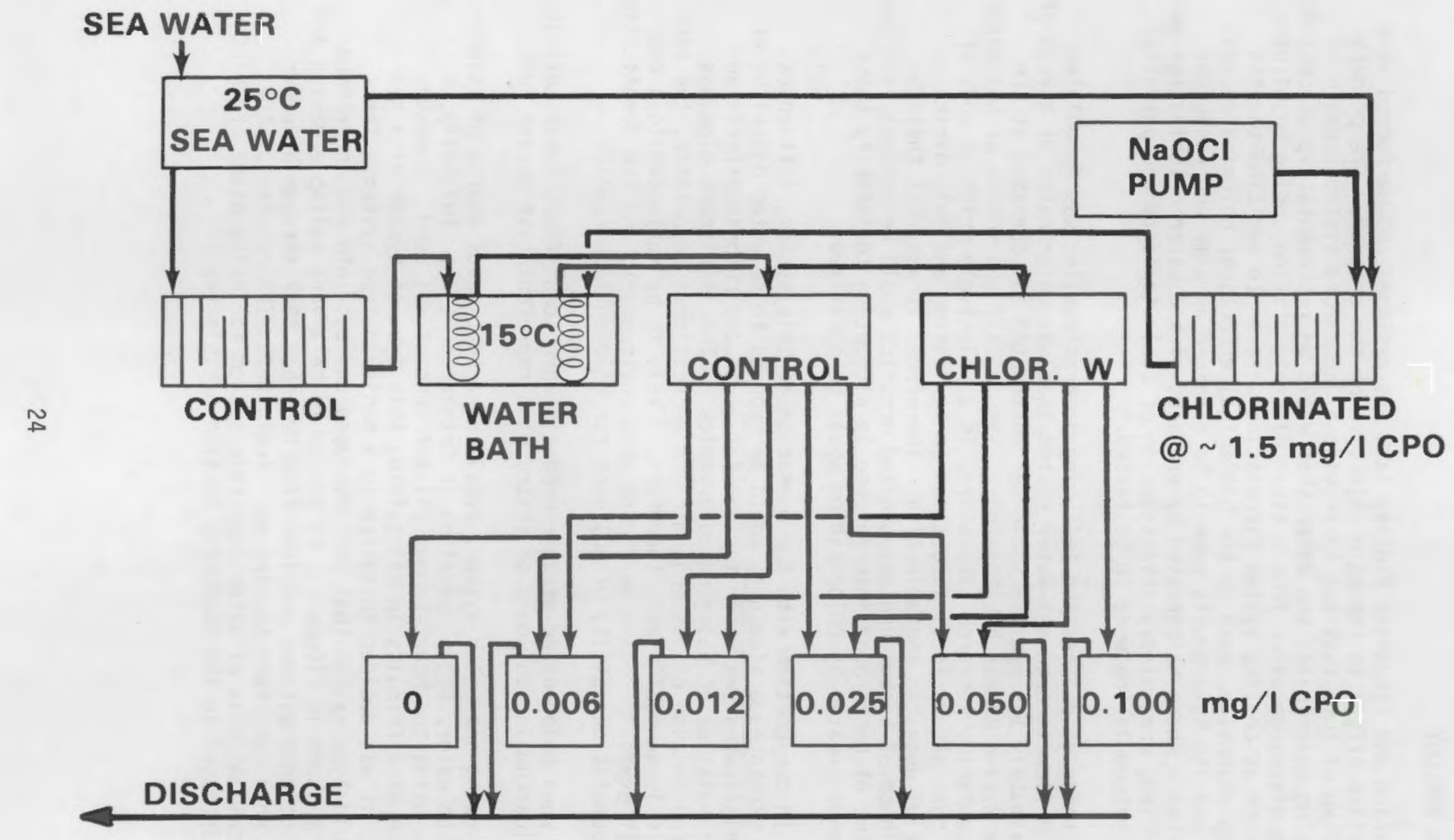

FIGURE 7. Toxicant Delivery System for Sea Water/Bromoform Bioassays Conducted at Sequim 
The littleneck clams exposed to chlor inated sea water were examined for growth effects, histological effects, and bram of orm accumulation. Groups of clams were exposed to chlorinated sea water/unchlorinated sea water mixtures that had in-tank Chlorine Produced 0xidant (CPO) concentrations of $0,6,12,25,50$, and $100 \mu \mathrm{g} / \mathrm{e}$. For histological purposes, clams were harvested from the exposure tanks after $1,2,3,4,5$, and 6 months of exposure. Clams for growth measurements and bromof orm analyses were harvested after $1,2,3,4,5,6$, and 8 months.

The histological examination of the clams indicated that they were in relatively poor condition after one month in the system. However, after the first month there was a general improvement at all test conditions.

Beyond the second month there was general improvement or maintenance of "status quo" for the organisms in the control, 6,12 , and $25 \mu \mathrm{g}-\mathrm{CPO} / \mathrm{e}$ test conditions and a general decline at the 50 and $100 \mu \mathrm{g}-\mathrm{CPO} / \ell$ conditions. Figures 8 and 9 compared digestive glands of the clam taken from the control tank after six months to digestive gland of clam exposed to $100 \mathrm{ppb}$ CPO for six months. Figures 10 and 11 compare gills and Figures 12 and 13 compare intestinal tissues after similiar treatments.

The growth data showed that the clams did not begin adding new shell in the 25,50 , and $100 \mu \mathrm{g}-\mathrm{CPO} / \mathrm{l}$ test conditions, but did show positive signs of growth after 5 months in the two lower concentrations and control conditions. A more detailed discussion of the results are provided in Gibson et al. (1980b).

The concentration of bromof orm found in the tissues of the clams harvested from the exposure tanks was relatively low ( 0 to $352 \mu \mathrm{g} / \mathrm{g}$ tissue) and did not show a pattern of bioconcentration (Table 8). The higher concentrations found in the clams in the first two months may be attributed to better conditions (more lipids) and/or possible contamination of the water supply by bramof orm vapor resulting fram toxicity tests being conducted in the same room at the same time. Use of bromoform in the room was discontinued on June 17 , therefore, the presence of bromoform in tissues after that date would have to be by uptake from the chlorinated sea water or retained from earlier uptake. Data from the uptake and depuration studies indicate that bromoform is depurated from clam tissues in 24 to 48 hours. However, the appearance of bromoform in the controls after June may indicate that very low concentrations may remain. Studies by Bean and Riley (1980) indicate that a $4 \%$ conversion of $\mathrm{Cl}_{2}$ to bromof orm expected in the test tank receiving $100 \% \mathrm{chl}$ orinated sea water would be approximately $60 \mu \mathrm{g} / \ell$. 


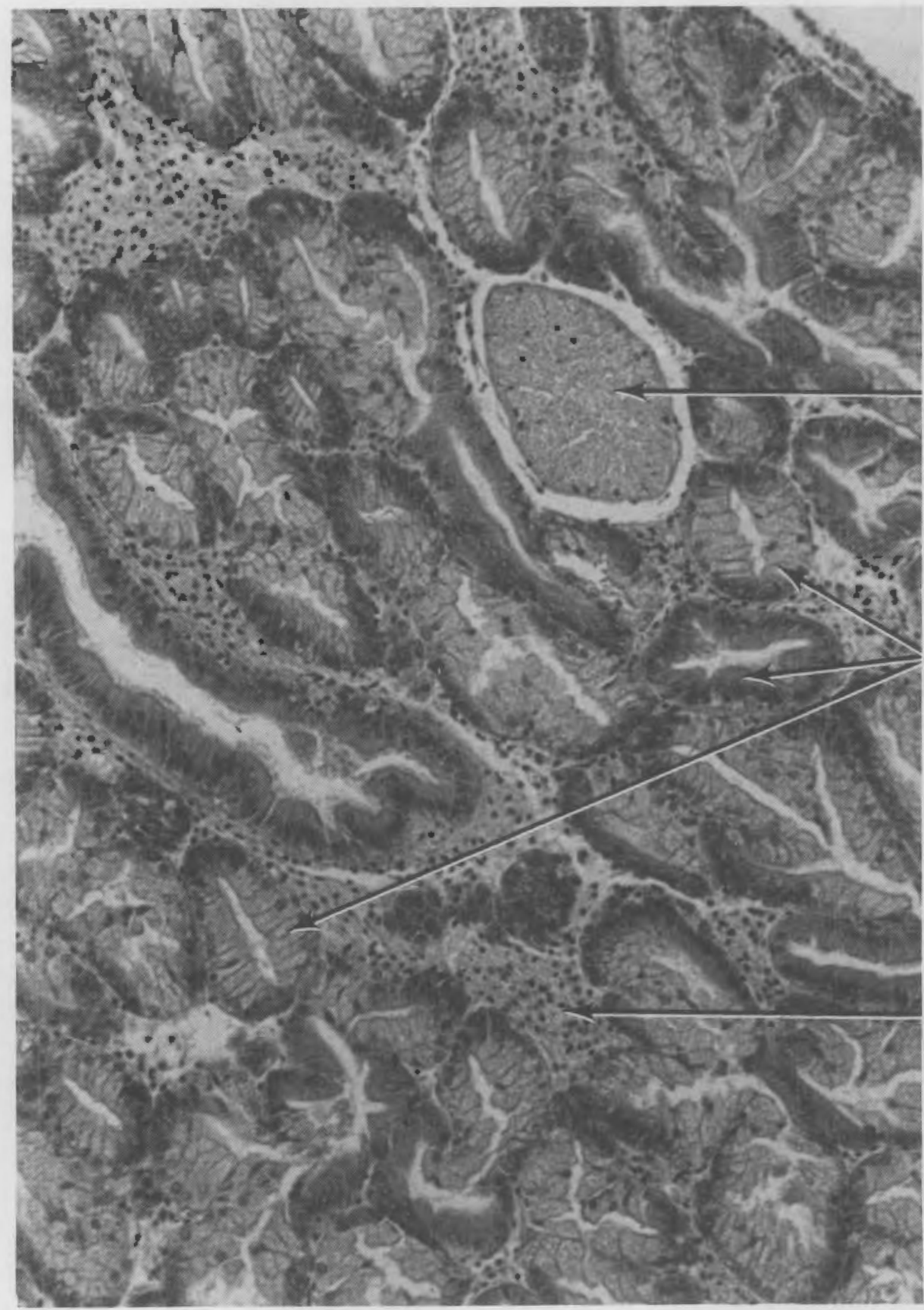

\section{CEREBRO- \\ VISCERAL CONNECTIVE \\ NERVE}

\section{DIGESTIVE}

TUBULES

\section{CONNECTIVE} TISSUE

FIGURE 8. Section Through Digestive Gland of $\mathrm{Clam}$ Exposed in Control Tank for 6 Months. Masson's Stain, $10 \times$ Objective. 


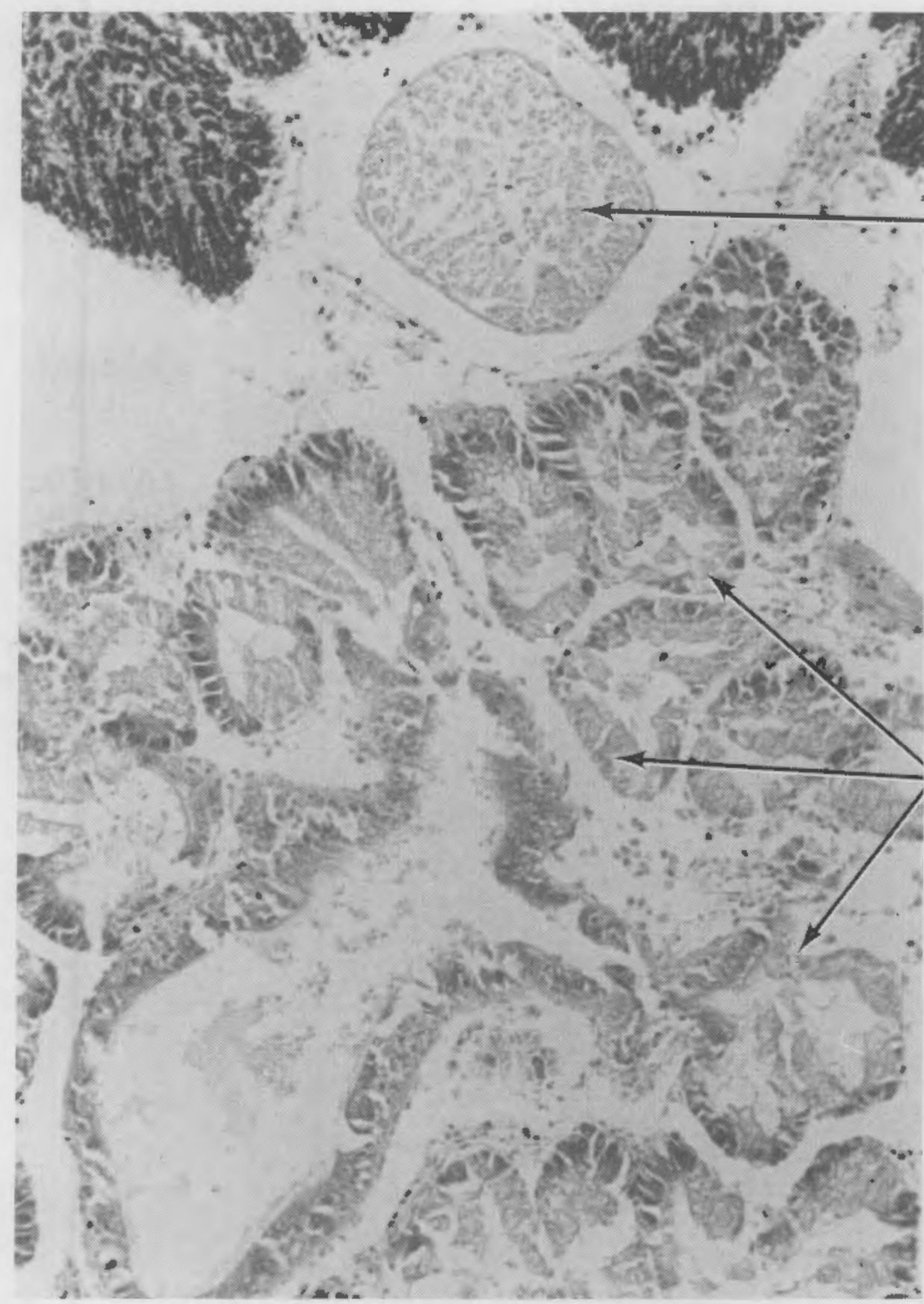

\section{CEREBRO- VISCERAL CONNECTIVE NERVE}

FIGURE 9. Section Through Digestive Gland of Clam Exposed to $100 \mathrm{ppb}$ CPO for 6 Months. Note Necrotic Nerve and Digestive Tubule, Tubule Epithelium, As : Well As Loss of Connective Tissue. Sections Tend to Stain Less Wel1. Masson's Stain, $10 \times$ Objective. 


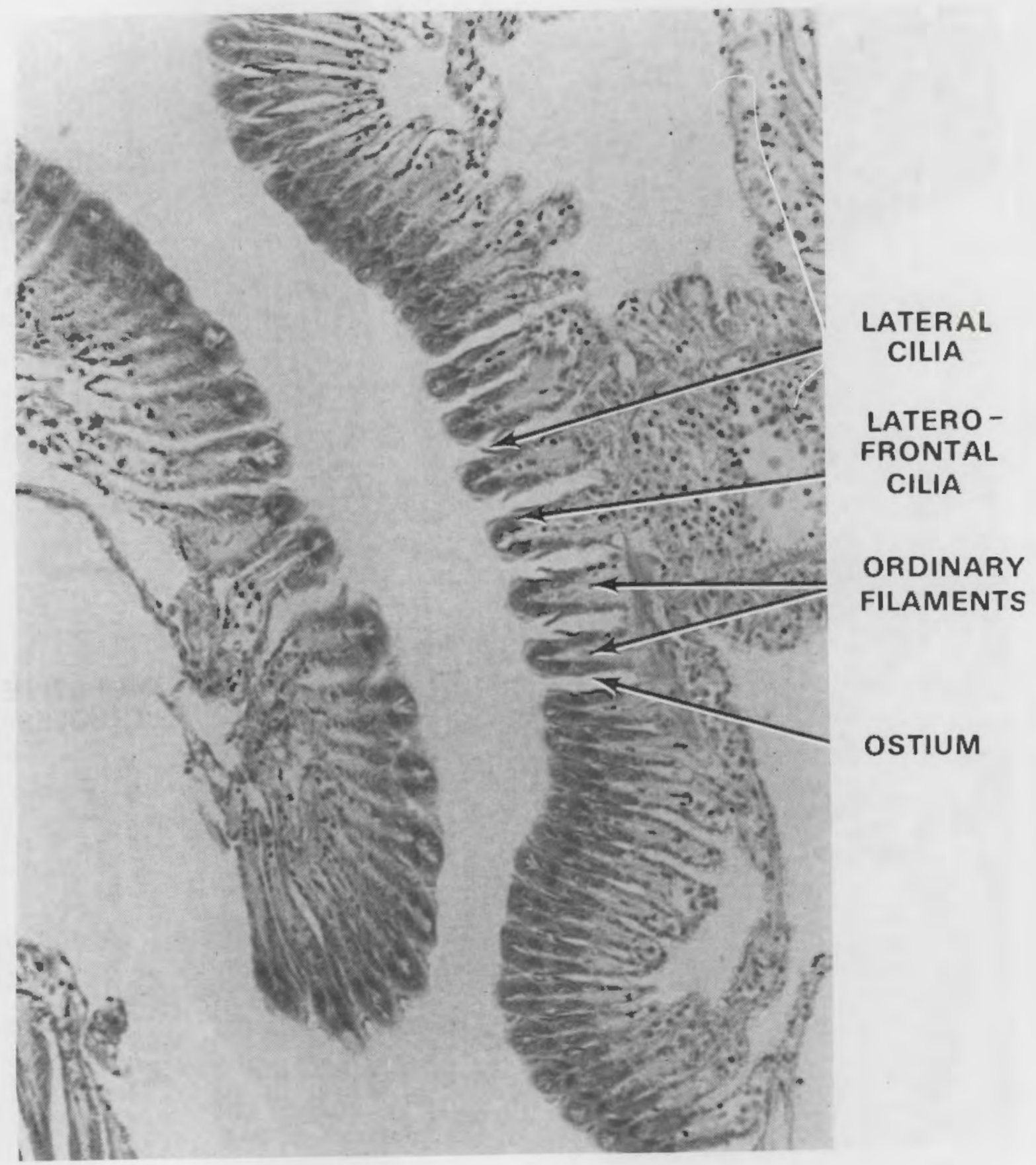

FIIGURE 10. Section Through Gill of Clam Exposed in Control Tank for 6 Months. Ordinary Filaments Are Distinct and the Tufts of Laterofrontal and Lateral Cilia Are Easily Seen. Masson's Stain, $10 \times$ Objective. 


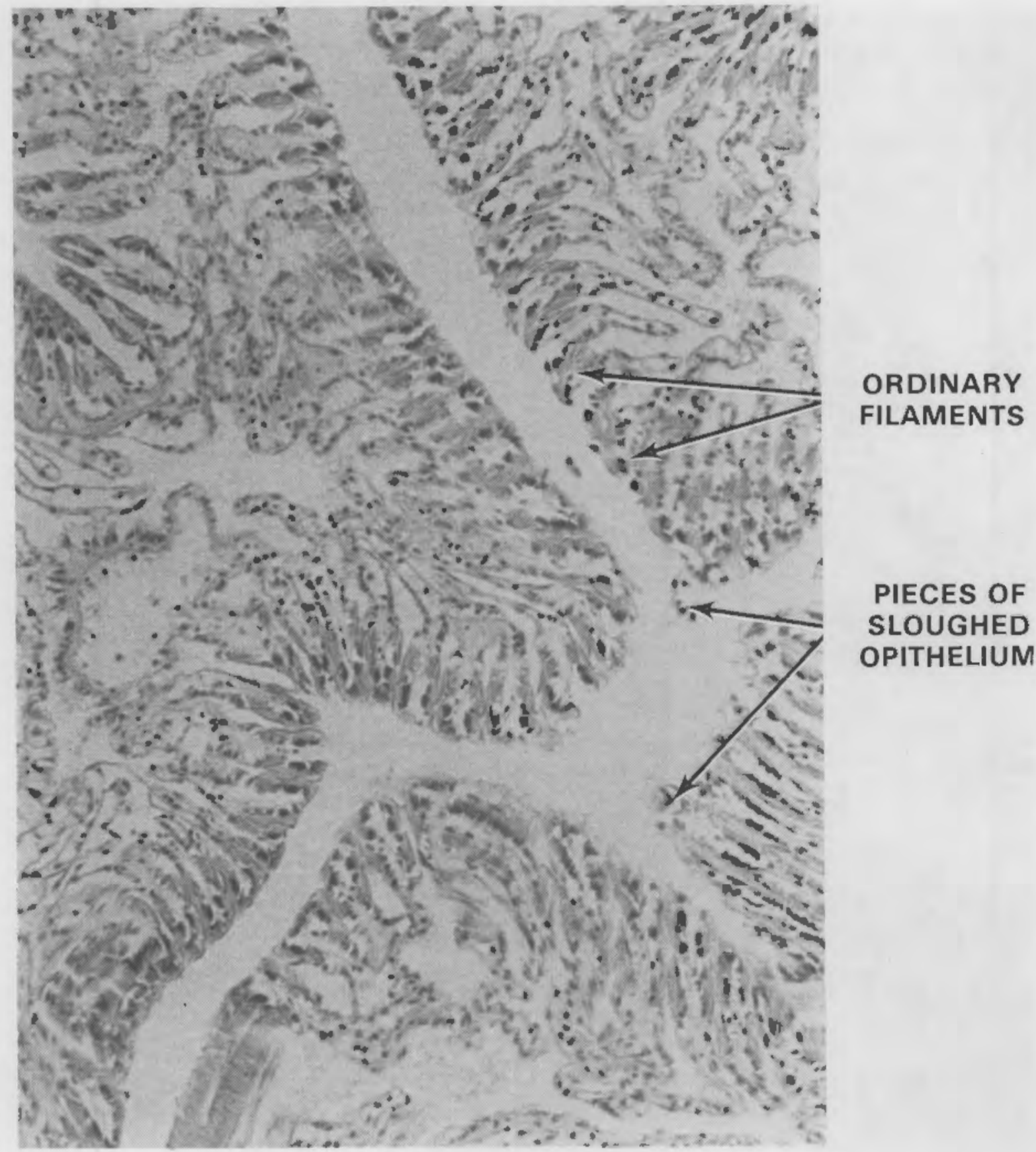

FIGURE 11. Section Through Gill of $\mathrm{Cl}$ am Exposed to $100 \mathrm{ppb} \mathrm{CP} 0$ for 6 Months. Note Necrotic Appearance of Filaments. Tips of Filaments are Indistinct and No Cilia Apparent. Sloughed Epithelium Can be Seen in Section. Masson's Stain, $10 \times$ Objective. 


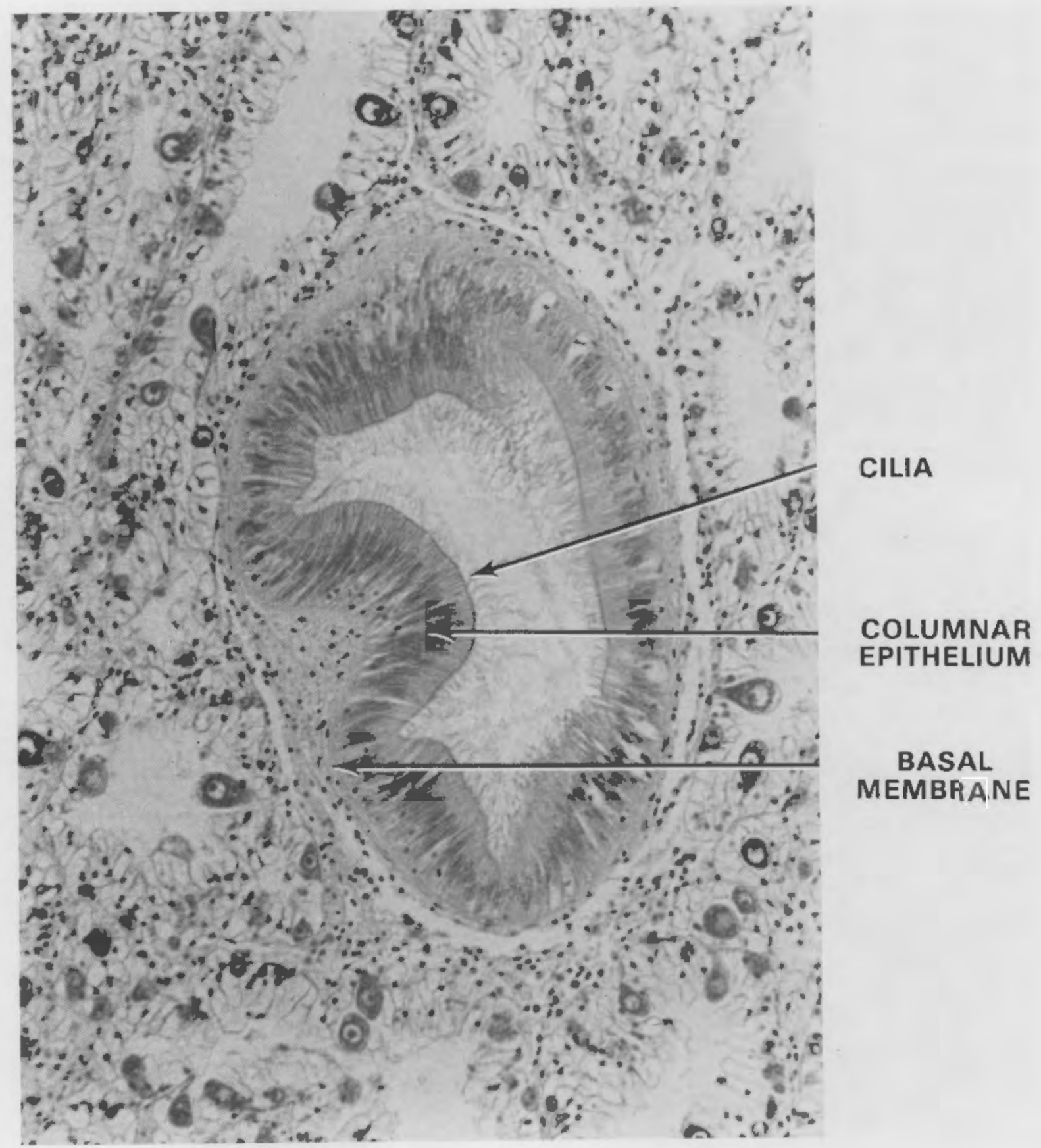

FIGURE 12. Section Through Intestine of Clam Exposed in Control Tank for 6 Months. Note Distinct Cilia Extending Into Lumen of Intestine. Columnar Epithelial Cells Are Heal thy Where Attached to Basal Membrane. Masson's Stain, $10 \times$ Objective. 


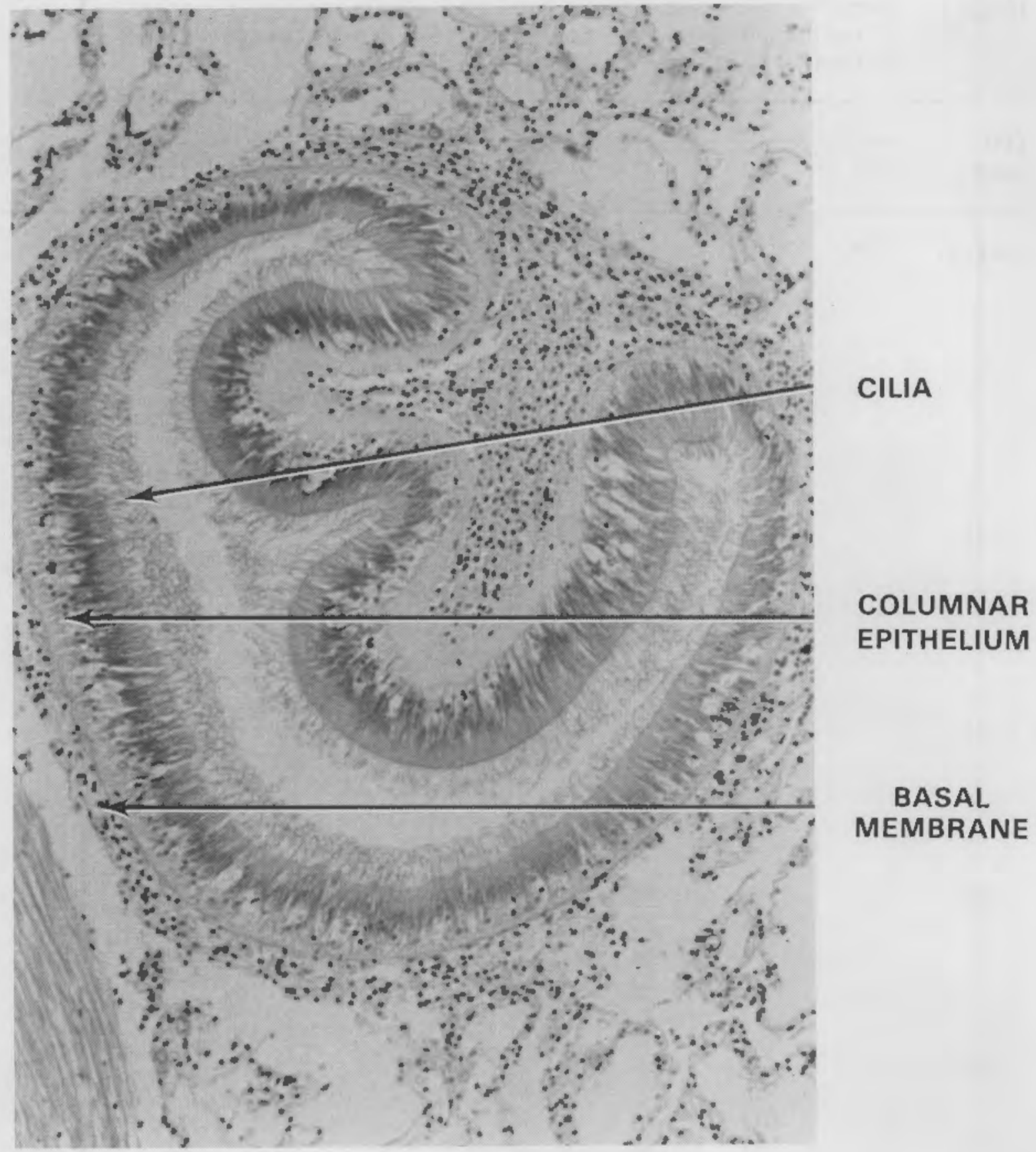

FIGURE 13. Section Through Intestine of Clam Exposed to $100 \mathrm{ppb}$ CPO for 6 Months. Note Increased Vacuolization and Necrotic Zone Near Basal Membrane. Masson's Stain, $10 \times$ Objective. 
TABLE 8. Bromoform Concentrations in Clams ( $\mu \mathrm{g} / \mathrm{g}$ wet wt) Exposed to Chlorinated Sea Water Containing Sublethal Concentrations of Chlorine Produced Oxidant ( $\mathrm{CPO})$.

\begin{tabular}{|c|c|c|c|c|c|c|c|c|}
\hline $\begin{array}{l}\text { CPO } \\
\mu \mathrm{g} / \mathrm{l}\end{array}$ & $3 / 1$ & $4 / 3$ & $5 / 2$ & $\begin{array}{l}\text { Date of } \\
5 / 30\end{array}$ & $\begin{array}{c}\text { Aarvest } \\
6 / 29\end{array}$ & $8 / 1$ & $9 / 5$ & $11 / 8$ \\
\hline Control & $0^{\star}$ & $\begin{array}{r}0 \\
226 \\
107\end{array}$ & $\begin{array}{l}0 \\
6 \\
0\end{array}$ & $\begin{array}{r}12 \\
5 \\
0\end{array}$ & N.D. & N.D. & $\begin{array}{r}0 \\
10 \\
0\end{array}$ & $\begin{array}{l}1 \\
9 \\
0^{a}\end{array}$ \\
\hline 6 & . & $\begin{array}{r}97 \\
166 \\
0\end{array}$ & $\begin{array}{r}20 \\
15 \\
0\end{array}$ & $\begin{array}{l}0 \\
0 \\
0\end{array}$ & $\begin{array}{l}0 \\
0 \\
0\end{array}$ & $\begin{array}{l}2 \\
0 \\
0\end{array}$ & $\begin{array}{l}0 \\
0 \\
0\end{array}$ & $0^{b}$ \\
\hline 12 & & $\begin{array}{r}33 \\
183 \\
238 \\
296\end{array}$ & $\begin{array}{r}56 \\
9 \\
0\end{array}$ & $\begin{array}{r}2 \\
169 \\
0 \\
9\end{array}$ & $\begin{array}{l}0 \\
0 \\
0 \\
0\end{array}$ & $\begin{array}{r}0 \\
10 \\
14 \\
18\end{array}$ & $\begin{array}{r}1 \\
9 \\
3 \\
20 \\
0\end{array}$ & $\begin{array}{r}2 \\
40 \\
0^{C}\end{array}$ \\
\hline 25 & & $\begin{array}{r}24 \\
123 \\
74 \\
42\end{array}$ & $\begin{array}{l}72- \\
13 \\
80 \\
39\end{array}$ & $\begin{array}{r}348 \\
26 \\
20 \\
9\end{array}$ & $\begin{array}{r}17 \\
0 \\
0 \\
35\end{array}$ & $\begin{array}{l}18 \\
14 \\
14 \\
17\end{array}$ & $\begin{array}{r}0 \\
0 \\
208\end{array}$ & $\begin{array}{l}3 \\
2 \\
2 \\
0 \\
0\end{array}$ \\
\hline 50 & & $\begin{array}{r}107 \\
34 \\
97 \\
352\end{array}$ & $\begin{array}{r}21 \\
16 \\
6 \\
82\end{array}$ & $\begin{array}{r}7 \\
11 \\
1 \\
8\end{array}$ & $\begin{array}{l}13 \\
44 \\
25 \\
41\end{array}$ & $\begin{array}{r}4 \\
0 \\
0 \\
14\end{array}$ & $\begin{array}{l}0 \\
0 \\
0 \\
0\end{array}$ & ${ }_{0}^{2} \mathrm{e}$ \\
\hline 100 & & $\begin{array}{r}72 \\
95 \\
103 \\
89\end{array}$ & $\begin{array}{r}150 \\
153 \\
64 \\
60\end{array}$ & $\begin{array}{l}14 \\
43 \\
46 \\
32\end{array}$ & N.D. & $\begin{array}{r}0 \\
22 \\
26 \\
8\end{array}$ & $\begin{array}{l}6 \\
2 \\
0 \\
2\end{array}$ & $\begin{array}{r}18 \\
28 \\
22 \\
0\end{array}$ \\
\hline
\end{tabular}

\footnotetext{
‡ Represents 13 individuals

a Represents 9 individuals

b Represents 11 individuals

c Represents 4 individuals

d Represents 7 individuals

e Represents 6 individuals

Represents 4 individuals
} 
The finding of bromoform in the control system raises questions about the possible compounding effect this could have had on the organisms in the growth and histological studies. An examination of the data does not reveal any such effect. The phenomenons noted (growth inhibition and general cellular degradation) maintain a trend that was consistent through the whole exposure period and directiy related to CPO concentrations. The bromoform was present in the room only through the first 4 months of the study and would have been in equal concentrations in all systems. Although these observations do not rule out combined effects, it appears that the phenomenons observed were due to the chlorinated sea water and related to the concentration of CPO present.

\section{Acute Toxicity and Bioaccumulation of Bromoform}

Bromoform was identified as the major halogenated organic created by the chlorination of sea water and, therefore, a series of bioassays were undertaken to determine its toxicity to commerciaily and recreationally important marine species. The species selected by NRC to be tested were the Eastern oyster (Crassostrea virginica), Eastern hardclam (Mercenaria mercenaria), brown shrimp (Penaeus aztecus), Menhaden (Brevoortía Eyrannus), and ittleneck ciam (Protothaca staminea). Toxicity testing was done in flow-through systems that had bromoform injected via spraging the sea water with air saturated with bromoform. The testing of bromoform for toxicity was difficult because of its volatility, the difficulty in getting it into solution, and the narcotic effect on organisms. However, the 96-hr LC 50 's (Table 9) show that it requires concentrations 2 to 3 orders of magnitude above those expected to be produced via normal chlorination practices to produce acute effects. Details of the testing methods and results are presented in Gibson et a). (1979).

Bioaccumulation and depuration studies with bromoform were conducted with the same five marine species. Again, the establishment of constant concentration of bromoform in seawater presented a major problem. However, the results indicate that for the mollusks (oysters, eastern clams, and littleneck clams) the body burdens were similar to water. concentrations, whereas, for the brown shrimp and menhaden there were indications of biomagnification at lower water concentrations but that a maximum body burden was attained. In all species, the bromoform was depurated within 24 to 48 hours after exposure was terminated. The details of these tests are provided in Gibson et al. (1980a). 
TABLE 9. Mortality and Average Exposure Concentrations for the 96-hr Exposure of Shrimp, Clams, Menhaden and Oysters to Bromoform.

\begin{tabular}{|c|c|}
\hline $\begin{array}{r}\text { Water Concentrations } \\
\mathrm{mg} / \ell\end{array}$ & $\begin{array}{r}\% \text { Mortalit } \\
96 \text { hou } \\
\end{array}$ \\
\hline \multicolumn{2}{|l|}{ Shrimp: } \\
\hline $\begin{array}{l}57 \\
47 \\
43 \\
39 \\
31 \\
26.5 \\
19 \\
16 \\
9.4 \\
3.3\end{array}$ & $\begin{array}{r}100 \\
100 \\
100 \\
85 \\
40 \\
40 \\
15 \\
15 \\
5 \\
0\end{array}$ \\
\hline
\end{tabular}

* Calculated $\mathrm{LC}_{50}-26 \mathrm{mg} / \mathrm{\ell}-95 \%$ Confidence Interval $33 \mathrm{mg} / \ell$ to $20 \mathrm{mg} / \mathrm{\ell}$

Menhaden:

$\begin{array}{lr}39.5 & 100 \\ 19.75 & 100 \\ 13.8 & 100 \\ 8.55 & 30 \\ 6.0 & 10\end{array}$

* Calculated $L_{5} C_{5}-12 \mathrm{mg} / \ell$ - $95 \%$ Confidence Interval $15 \mathrm{mg} / \ell$ to $9 \mathrm{mg} / \mathrm{l}$

Oysters:

$\begin{array}{lrl}39.5 & 10 & 50 \\ 19.75 & 0 & 20 \\ 13.8 & 0 & 10 \\ 8.55 & 0 & 20 \\ 6.0 & 0 & 20 \\ \text { Control } & 0 & 10\end{array}$

Insufficient mortality to calculate $L C_{50}$

Clams:

$\begin{array}{rr}62.7 & 20 \\ 40.5 & 10 \\ 21.0 & 0 \\ 9.2 & 0 \\ 0.5 & 0 \\ 0.32 & 0\end{array}$

Insufficient mortality to calculate $L_{50}$

* LC50 calculated by the method of Litchfield and wilcoxon (1949) 
CUNCLUSIONS

- Chlorination of natural waters in concentrations of a few milligrams per liter results in an increase in the quantitiy of chlorinated organic material which can be extracted using XAD-2 resins.

- Haloforms are the predominant stable lipophilic products resulting from the low level chlorination of natural waters. Concentrations of haloforms found in these studies ranged from 2 to $55 \mu \mathrm{g} / \mathrm{l}$. Haloforms account for most of the organically bound chlorine found in XAD-2 extracts of the water.

- Concentrations of nonhaloform stable lipophilic halogenated compounds produced by low level water chlorination appear to be very low, on the order of nanograms per liter. Less stable products, such as halogenated amines may be found in higher concentrations, but would not De detected with the procedures used.

- Irace amounts of bromide in fresh water bodies have a profound influence on the distribution of haloform types produced by chlorination. Bromide concentrations in excess of ten micrograms per liter produced significant quantities of mono- and dibrominated naloforms.

- Halogenated phenols have been found to be chlorination products in seven of the ten locations. They were not found in chlorinated seawater, but were found at the Cape Fear estuary, which contained fifty percent sea water.

- Given the time and exposure conditions of a 6 -mo exposure, there was no appparent long-term effect of low-level chlorination on rainbow trout mortality or growth.

- Kainbow trout tissues from the first chronic chlorination by-products exposure at 6-mo were analyzed for chlorinated organics. No significant differences in chlorinated organics were found between exposed and control fish.

- Measurement of chloroform in the fresh water exposure apparatus using headspace technique shows that chloroform levels range from $\mathrm{l} \mu \mathrm{g} / \mathrm{l}$ to $0.5 \mathrm{\mu g} / \mathrm{l}$. Chloroform concentrations in the unchlorinated controls range from non-detectable to $0.5 \mu \mathrm{g} / \mathrm{l}$.

- under the test conditions used, CPO concentrations of 50 and 100 $\mu \mathrm{g} / \mathrm{l}$ had an adverse effect on the growth of littleneck clams. However, the control group and groups exposed to target CPO concentrations of 6,12 , and $25 \mathrm{\mu g} / 2$ had positive growth. 
- Histological examination of the clams showed stress conditions at the beginning of the exposure, but the clams in the control and lower CPO concentrations $(6,12$ and $25 \mu \mathrm{g} / \mathrm{l})$ recovered while those at the higher concentrations (50 and $100 \mu \mathrm{g} / \ell$ ) had significant tissue damage at the end of the test period ( 6 months).

- The ultimate consequences of the lack of growth and tissue damage on the ability of the clams to survive and reproduce was not determined. However, the data indicates that clan populations that are continually exposed to $C P O$ concentrations of $50 \mu \mathrm{g} / \mathrm{l}$ or higher will be under greater stress than those exposed to concentrations of $25 \mu \mathrm{g} / \mathrm{h}$ or less.

- The 96-hr LC 50 's were $18.2 \mathrm{ppm}$ for rainbow trout and bluegill, $5 i .2 \mathrm{ppm}$ for largemouth bass and $75 \mathrm{ppm}$ for channel catfish.

- Although chloroform was observed to be lethal to these fish, lethal levels are several orders of magnitude above that expected to be produced under normal power plant operating conditions. Observed changes in fish behavior also occurred at chloroform threshold levels above that expected to be discharged from power plants.

- Chloroform accumulated in fish tissues at three to seven times the water concentration during exposure of up to $4 \mathrm{hr}$, but rapid depuration of tissue chloroform levels was observed in most species.

- Although most power plants sited on fresh water normally chlorinate intermittently, accumulation of chloroform in fish tissues can be expected during these short term exposures.

- Toxicity tests on marine organisms with bromoform have indicated that for brown shrimp the calculated $96-\mathrm{hr} \mathrm{LC}_{50}$ is $26 \mathrm{mg} / \mathrm{l}$. The 96-hr LC 50 concentration for menhaden was calculated to be $12 \mathrm{mg} / \mathrm{l}$. Behavioral changes were observed in both menhaden and shrimp exposed to sublethal concentrations of bromoform. The extent and consequences of the behavioral changes noted on the survival of the shrimp and menhaden are not known.

- Standard 96-hr LC50 values for bromoform were not calculated for littleneck clams, quahogs or Eastern oysters. Based on latent mortalities and mortalities in the 28-day uptake exposures, it is estimated that the $96-\mathrm{hr} L C_{50}$ value would be greater than 30 to $40 \mathrm{mg} / \mathrm{l}$.

- Al1 species tested rapidly took and depurated bromoform. The mollusk species had tissue concentrations that were above water concentrations during the first week of exposure, but the tissue concentrations decreased during the last three weeks of exposure and were reflective of the ambient water concentrations. 
- In shrimp and menhaden the tissue concentrations were also highest during the first week of exposure. After that they fell to a concentration of approximately $0.4 \mu \mathrm{g} / \mathrm{g}$ and remained there for the remaining three weeks of exposure. The tissue concentrations of $0.4 \mathrm{\mu g} / \mathrm{g}$ appear to be maintained independent of the water concentration. 



\section{RECOMMENDATIONS}

- Although haloforms have been identified to be the major products of low-level chlorination of natural waters, with other lipophilic products formed in much lower amounts, a sampling program should be undertaken at nuclear power stations to verify these findings, and to determine the effects of plant operations on the quantities and distributions of halogenated organic products.

- Future research should examine the long term effects of repeated accumulation and depuration of chloroform that fish may experience as a result of power plant chlorination.

- Given the lipophilic nature of chloroform and the high lipid content of fish eggs relatively high chloroform concentrations may occur in the developing gonads of femaie fish. The implications of this to fish reproduction are unknown.

- Studies of the combined effects of chlorine and chlorination by-products should be conducted since these will occur simultaneously in power plant discharges and the demonstrated effects of chlorine on membrane permeability may exacerbate the effects of chlorination by-products.

- Studies are also recomended in the long-term effects of chloroform on reproduction, carcinogenicity, teratogenicity and mutagenicity in fresh water biota.

- Field sampling of mollusk populations exposed to CPO should be undertaken to verify the existence of similar tissue damage in the natural environment. 



\section{REFERENCES}

Anderson, D. R., and E. W. Lusty. 1980. Acute Toxicity and Bioaccumulation of Chloroform to Four Species of Fresh Water Fish. NUREG/CR-0893. Prepared by Battelle, Pacific Northwest Laboratories, for the U.S. Nuclear Regulatory Commission.*

Bean, R. M., R. G. Riley, and P. W. Ryan. 1978. "Investigation of halogenated components formed from chlorination of marine water, "pp. 223-234. In: Water Chlorination; Environmental Impact and Health Effects, R. L. JoTTey, H. Gorchev and D. H. Hamitton, Jr., (ed.). Ann Arbor Science, Ann Arbor, MI.

Bean, R. M., and R. G. Riley. 1980. Investigation of Halogenated Components Formed from Chlorination of Natural Waters: Preliminary Studies. NUREG/CR-1299. Prepared by Battelle, Pacif ic Northwest Laboratories for the U.S. Nuclear Regulatory Comission.*

Bean, R. M., D. C. Mann, and R. G. Riley. 1980. Analysis of Organohalogen Products from Chlorination of Natural Waters Under Simulated Biofouling Control Conditions. NUREG/CR-1301. Prepared by Battelle, Pacific Northwest Laboratories, for the U.S. Nuclear Regulary Commission. *

Bellar, T. A., and J. J. Lichtenberg. 1974. Determining volatile organics at microgram-per-liter levels by gas chromatography. J. An. Water Works Assoc. 66:739-744.

Bush, B., R. S. Narang, and S. Syrotynski. 1977. Screening for haloorganics in New York State drinking water. Bull. Env. Cont. and Toxicol. 18:436-440.

Carpenter, J. H., and C. A. Smith. 1978. "Reactions in chlorinated seawater," pp. 195-208. In: Water Chlorination - Environmental Impact and Health Effects, Vol. 2. R. L. Jolley, H. Gorchev, D. H. Hamition, Jr., (ed.). Ann Arbor Science, Ann Arbor, MI.

Dowty, B. J., D. R. Carlisle, and J. L. Laseter. 1975. New Or leans drinking water sources tested by gas chromatography-mass spectrometry. Env. Science and Technol. 9:762-765.

Dressler, M. 1979. Extraction of trace amounts of organic compounds from water with porous organic polymers. J. Chromatog. 165:167-206.

Drozd, J., and J. Novak. 1979. Headspace analysis by gas chromatography. J. Chromatog. 165:141-165.

Eppley, R. W., E. H. Renger, and P. M. Williams. 1976. Chlorine Reactions with Sea water Constituents and the Inhibition of Photosynthesis of Natural Marine Phytoplankton. Est. and Coast. Mar. Sci. 4:147-161. 
Gehrs, C. W., L. 0. Eyman, R. J. Jolley, and J. E. Thompson. 1974. Effects of Stable Chlorine-containing organics on aquatic environments. Nature 249:675-676.

Gibson, C. I., F. C. Tone, P. Wilkinson and J. W. Blaylock. 1979. Toxicity and effects of bromoform on five marine species. Ozone: Science and Engineering 1:47-54.

Gibson, C. I., F. C. Tone, R. E. Schirmer and J. W. Blaylock, 1980a. Observations on bioaccumulation and depuration of bromoform in five marine species. In: Proceedings of the Third Conference on water Chlorination. Colorado Springs, C0., October 28-November 2, 1979 .

Gibson, C. I., R. E. Hillman, P. Wilkinson, and D. L. Woodruff. 1980b. Growth and Histological Effects to Protothaca staminea (Littleneck Clam) of Long-Term Exposure to Chlorinated Sea Water. NUREG/CR-1298. Prepared by Battelle, Pacific Northwest Laboratories for the U.S. Nuclear Regulatory Commission.*

Glaze, W. H., J. E. Henderson, IV, and G. Smith. 1975. "Analys is of new chlorinated organic compounds formed by chlorination of municipal wastewater", pp. 153-175. In: Proc. Conf. on the Environmental Impact of Water Chlorination. R. L. Jolley, ed. Oak Ridge National Laboratory, Oak Ridge, TN.

Glaze, W. H., and J. E. Henderson, IV. 1976. Formation of organochlorine compounds from the chlorination of a municipal secondary effluent. 3. Water Pollut. Cont. Fed. 47:2511-2515.

GTaze, W. H., J. E. Henderson, IV, and G. Smith. 1976. "Analys is of new chlorinated organic compounds in municipal wastewaters after terminal chlorination", pp. 155-176. In: Identification and Analysis of Organic Pollutants in Water, L. H. Keith, ed. Ann Arbor, MI.

Glaze, W. H., G. R. Peyton and R. Rawley. 1977. Total organic halogen as water quality parameter: adsorption/microcoulometric method. Env. Sci. and Tech. 11:685-690.

Hamilton, D. H. 1978. "Chlorine Application for the Control of Condensor Fouling", In: Water Chlorination, Environmental Impact and Health Effects. $\sqrt{2}$. R. L. Jolley, ed., Ann Arbor Science, Ann Arbor, MI. pp. 687-693.

Helz, G. R., and R. Y. Hsu. 1979. Volatile chloro- and bromocarbons in coastal waters. Limnol. Oceanog. 23 $23(5): 858-869$.

JolTey, R. L. 1975. Chlorine-containing Organic Constituents in Chlorinated Effluents. J. Water Pollut. Cont. Fed. 47:601-618. 
Jolley, R. L., G. Jones, W. W. Pitt, and J. E. Thompson. 1975.

"Chlorination of Organics in Cooling Waters and Process Effluents." In: Proceedings of Conference on Environmental Impact of Water Chlorination, CONF-751096, R. L. Jolley, ed., p. 115, National Technical Information Service, Springfield, VA.

Jolley, R. L. 1977. Identification of Organic Halogen Products. Chesapeake Scjence 18:122-125.

Junk, G. A., J. J. Richard, M. D. Brieser, D. Witiak, J. L. Witiak, M. D. Arguello, R. Vick, H. J. Svec, J. S. Fritz, and G. B. Calder. 1974. Use of macroreticular resins in the analysis of water for trace organic contaminants. ‥ Chromatog. 99:745-762.

Junk, G. A., J. J. Richard, J. S. Fritz, and H. J. Svec. 1976. "Resin sorption methods for monitoring selected contaminants in water." pp. 134-153. In: Identification and Analys is of Organic Pollutants in Water. L. H. Keith (ed.). Ann Arbor Science, Ann Arbor, MI.

Litchfield, J. T., Jr., and F. W. Wilcoxon. 1949. A simplified method of evaluating dose-effect experiments. J. Pharmacol. Exp. Theraput. 96:99-113.

0liver, B. G. 1978. Chlorinated non-volatile organics produced by the reaction of chlorine with humic materials. Canadian Research. $11(6): 21-22$.

Roesijadi, G., S. R. Petrocelli, J. W. Anderson, C. S. Giam, and G. E. Neff. 1976. Toxicity of Polychlorinated Biphenols (Aroclor 1254) to Adult, Juvenile, and Larval Stages of the Shrimp, Palaemonetes pugi. Bull. Env. Contam. and Toxicol. 15:297-304.

Rook, J. J. 1974. Formation of haloform during chlorination of natural waters. Water Treat. and Exam. 23:234-243.

Sprague, J. B. 1973. "The ABCs of pollutant bioassay using fish," pp. 6-30. In: Biological Methods for the Assessment of Water Quality. ASTM-STP-528, American Society for Testing and Materials.

Stephan, C. E. 1977. Methods for Calculating an $\mathrm{LC}_{50}$. pp. 65-84. In: Aquatic Toxicology and Hazard Evaluation, ASTM STP 634, F. L. Mayer and J. L. Hamelink, Ed., American Society for Testing and Materials.

Zitko, V., and 0. Hutzinger. 1976. Uptake of Chloro- and Bromobiphenyls, Hexachloro- and Hexabromobenzene by Fish. Bull. Env. Contr. and Toxic. 16:665-673.

\#AvaiTabTe for purchase from the NRC/GPO Sales Program, U.S. Nuclear Regulatory Commission, Washington, D.C. 20555, and the National

Technical Information Service, Springfield, VA 22161. 

No. of

Copies

OFFS ITE

A. A. Churm

DOE Patent Division

9800 S. Cass Avenue

Argonne, IL 60439

Dr. Phillip R. Reed

Bob Samworth

John C. Lehr

U.S. Nuclear Regulatory

Commission

7915 Eastern Avenue

Silver Springs, MD 20901

265 NRC Division of Technical Information and Document Control

Washington, OC 20555

2 DOE Technical Information Center

D. R. Anderson

2521 N. 40th, No. 1

Seattle, WA 98103

Or. Robert Broxton

Electric Power Research Institute

P.0. Box 10412

Palo Aito, CA 94303

Dr. Dennis T. Burton

Academy of Natural Sciences of Philadelphia

Benedict Estuarine Research Laboratory

Benedict, MO 20612

\section{DISTRIBUTION}

No. of

Copies

Dr. Will Davis

U.S.E.P.A.

Guif Breeze Environmental

Research Laboratory

Wadmalaw Island, SC 19487

Dr. R. E. Hiliman

W. F. Clapp

Laboratories

Washington Street, P.0. Box AH

Duxbury, MA 02332

Dr. Oonald Johnson

Dept. Environmental Sciences and Engineering

School of Public Health

University of North Carolina

Chapel Hil1, NC 27514

Dr. George R. Helz

Chemistry Dept.

University of Maryland

College Park, MO 20742

Dr. Milton H. Leitzke

P.0. Box $x$

Oax Ridge National Laboratory

Dak Ridge, TN 37830

Dr. J. S. Mattice

P.0. Box $x$

Dak Ridge National Laboratory

Oak Ridge, TN 37830

Or. John Lum

U.S.E.P.A.

401 M Street S.W.

WH552

Washington, DC 20460 
No. of

Copies

Dr. Roy Nakatani

Dr. Quentin J. Stober

FRI WH-10

University of Washington

Seattle, WA 98195

Dr. Thomas 0. Thatcher

Rt 2 Box 113

Sequim, WA 98382

F. C. Tone

F) orida Marine Research Facility Sailfish Drive

Ponce Iniet

Daytona Beach, FL 32019

Ronald L. Raschke

U.S. EPA

S.E. Water Laboratory

Bailey Road

Athens, GA 30601
No. of

Copies

ONSITE

50 Pacific Northwest Laboratory

RM Bean (32)

CI Gibson

KE Harding (4)

DC Mann

TL Page

RG Riley

RE Schirmer

NM Sherer

RE Wildung

Publishing Coordination (2)

Technica? Information (5) 


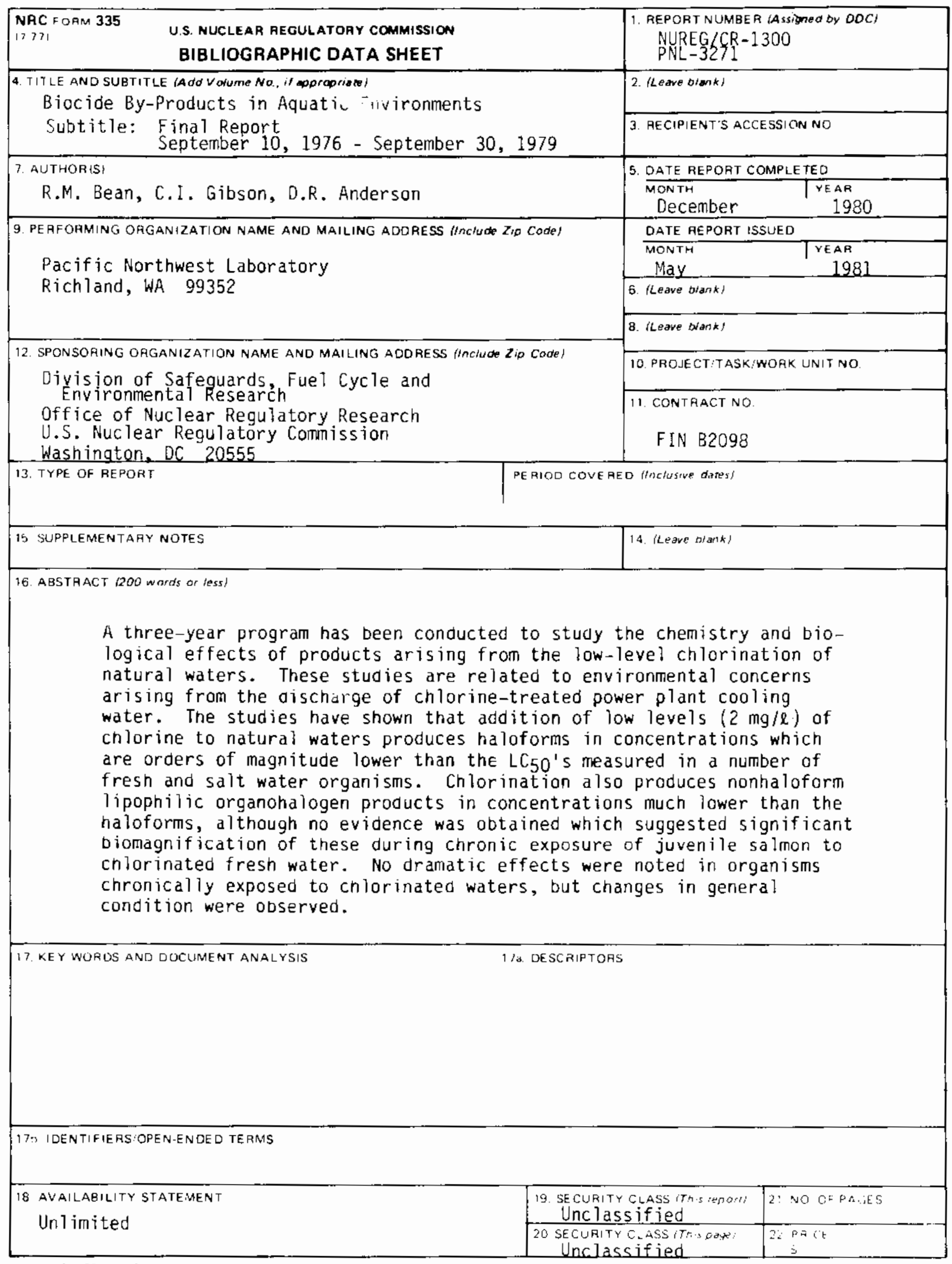


